\title{
WETLANDS DEGRADATION AND CONVERSION DUE TO URBANISATION IN MUMBAI METROPOLITAN REGION: ACUTE PROBLEMS WITH LONG TERM SOLUTIONS
}

\author{
Sanjay RODE \\ Department of Economics, S.K.Somaiya College, \\ Mumbai University, Mumbai, India \\ sanjayjrode@gmail.com
}

\begin{abstract}
Wetlands are providing ecosystem services to human communities. They support food production, water treatment and water supply, flood control, fishing, recreation and wildlife habitat. But wetlands area is shrinking very fast all over to world due to high urbanization. In developing countries, the destruction of wetlands is widely observed. In India, the wetlands area, size and number is declining very fast due to population growth and urbanization. Mumbai Metropolitan Region is not exception to this phenomenon. The wetland area is significantly declining in all suburbs of region over the period of time. The ordinary least square regression result shows that solid waste, agriculture and other land is negatively co-related to wetland in all suburbs of Mumbai Metropolitan Region. In all the suburbs, the wetland and forest land is converted for built up area. There is huge loss is earned annually and in past due to wetlands destruction in Mumbai suburb, Thane and Uran in region. The maximum loss is incurred for recreation and flood control. Therefore immediate policies are required to protect wetlands in region. State government should come out with future plans, legislation and co-ordination among various bodies, NGO's to protect wetlands in region. The protection, scientific conservation of wetlands will improve wetlands related services and welfare of people in region.
\end{abstract}

Keywords: Salinity, Urbanization, Recreation

\section{INTRODUCTION}

Earth is undergoing significant changes which are driven by natural and anthropogenic factors (Berezowski T. et.al 2018). Wetlands are important for ecosystem services, nutrient cycles, soil formation and water treatment. But almost half of the world's wetlands have disappeared in the last century because of agricultural and urban development (Ganbold o. et.al 2018). Wetland is called "kidney of the earth", the natural reservoir and species bank. The sight and cultural value makes great contribution to the perpetuation and development of world civilization. Sound wetland ecosystem is the important component of national ecological security system and the foundation of realizing the sustainable development of economy and society (Hushulong Q. 2012). But now wetlands are one of the most threatened habitats of the world. All countries face the challenge of sustainable development of wetlands to a greater or lesser extent, but the problem is especially urgent in developing countries 
Rode S.

WETLANDS DEGRADATION AND CONVERSION DUE TO URBANISATION IN MUMBAI METROPOLITAN REGION: ACUTE PROBLEMS WITH LONG TERM SOLUTIONS

(Wang Y., et.al 2008). Wetlands in India, as elsewhere are increasingly facing several anthropogenic pressures. Thus, the rapidly expanding human population, large scales changes in land use/ land cover, burgeoning development projects. Water sheds have all caused a substantial decline of wetland resources of the country. Significant losses have resulted from its conversion threats from industrial, agricultural and various urban developments. These have led to hydrological perturbations, pollution and their effects. Unsustainable levels of grazing and fishing activities have also resulted in degradation of wetlands (Phukan P.and Ranjan Saikia (2014). Wetlands are particularly affected as a result of clearing of deep rooted native vegetation for agriculture (Delaney J. et.al 2016). One study shows the prevalence of huge change in wetland areas, expansion of non-hydrophytic plants, and high humaninduced disturbances. The highest rates of wetland area changes and disturbances are recorded (Woldemariam W. et.al 2018). In India, Such changes are visible in various wetland related surveys.

In Mumbai Metropolitan Region, urbanization is increasing very fast. People are migrating from rural and urban parts of state as well as other states. There is huge demand for housing due to high population growth. Due to demand and low supply of housing leads to huge rise in the prices of houses in Mumbai Metropolitan Region. Therefore slums and illegal settlements are constructed in region. Government is not able to provide housing to all people in region. Nearly sixty per cent of population is staying in slums in Mumbai city alone. Over the period of time, State government has changed the allocation of land for various purposes. Educational level of population has increased over the period of time. Therefore the per capita income of people has increased fast in region. High migration, lack of affordable housing has resulted into high growth of slums in region. Water supply to Municipal Corporations and Councils in region is provided from various dams. Every day thousands of million litres of drinking water is supplied in region. All the units such as households, garages, industries, educational institutions, entertainment and welfare institutions are getting regular water supply. Every day, they generate maximum sewage in region. The sewage is not treated completely in all Municipal Councils and Corporations. It is left untreated in rivers, ponds and wetlands. The untreated sewage damages the biodiversity in region and kills the birds, fish, mammals and other animals in water. The numbers of industries have also grown in region over the period of time. They produce different products required for day-today purposes to people and export variety of products regularly. Few industries are polluting air, water and soil. They discharge sewage and industrial waste in nearby ponds, rivers and sea. The high income groups in region are generating more solid waste. Every day, they shop bottled water, packed food and generate more solid waste. Such solid waste is not completely collected and processed in region by Municipal Councils and Corporations. Few tones of solid waste is collected and deposited at different landfill sites in each Municipal Council and Corporation of region. Such 
WETLANDS DEGRADATION AND CONVERSION DUE TO URBANISATION IN MUMBAI METROPOLITAN REGION: ACUTE PROBLEMS WITH LONG TERM SOLUTIONS

uncollected and untreated solid waste pollutes soil and air environment in region. The numbers of vehicles are increasing very fast in region due to high income of population. It leads to high congestion, noise and air pollution in region. State government is continuously widening old roads due to heavy traffic in each Municipal Corporation and Council. The state government always brings new infrastructural projects in region. These projects are mainly for transport purposes and it includes mono, metro and bullet train, express highway etc. For such projects, state government has overtaken maximum private land in region. There are number of instances under which private and public land is acquired and wet land related issues are created. In region, sewage treatment plants do not treat entire sewage water. Every day thousands of million liters of untreated sewage is getting mixed with fresh stock of river and sea water. The groundwater is affecting wetland salinity, particularly in closed-basin wetlands receiving groundwater discharge (Baugha J.W. et.al. 2018). Overall pollutions of water bodies and wetlands are increasing fast.

There are numbers of species exists in region and depending on wetlands. The mammals, fish and migratory birds are very sensitive to environmental degradation in region. Due to urbanization, the migrated birds, fishes and reptile animals are declining very fast in region. Due to affordable housing and amenities, people are migrating to Badlapur, Ulwe and Vasai region. Huge construction and real commercial projects are undertaken by builders. Such projects are destroying the biodiversity in such areas. The sewage, solid waste is not collected in these regions. Human factors are the major contributors for wetland degradation and alteration of biological community composition in these suburbs. The extent of urbanization and land-use activities strongly influence the species composition of wetland plant communities. The wetlands are degrading, with extensive human activity. The wetlands currently provide more provisioning and cultural services, while regulatory and supporting services are predominantly provided by urban wetlands, followed by reference wetlands, though they are highly impacted (Wondie A. 2018). The people in region are involved in destruction of wetlands. They are cutting forest, man grows and destroying water bodies. The land could be made available for slums. Therefore huge loss is observed every year due to decline in wetland and related services to region. Unfortunately, there are increasing conversion pressures on these valuable ecosystems for the production of food, fiber, and other products. The peat lands are being burned, ditched, and converted to other land uses. Similarly, mangrove ecosystems are being converted to other uses (Kolka R. K. et.al 2016). The major objective of this paper is to understand the area under wetlands in region and how much change took place in it over the period of time. Secondly to find out the statistical co-relate with the wetlands area in region. First part of the paper deals with data and methodology for this study. Second part explains about the wetland area and change took place in it over the period of time in 
Rode S.

WETLANDS DEGRADATION AND CONVERSION DUE TO URBANISATION IN MUMBAI METROPOLITAN REGION: ACUTE PROBLEMS WITH LONG TERM SOLUTIONS

metropolitan region. The last part explains about the regression results and policy implication for wetland conservation in region.

\section{DATA}

Data for this study is mainly collected from different sources. The population data of Mumbai Metropolitan Region is collected from 1971, 1981, 1991, 2001, 2011 census. The environment status reports of all Municipal Corporations in Mumbai Metropolitan Region are referred. The Asian Development Bank, World Bank reports, NGO's documents related to environment of Metropolitan Region are referred. The wetland related issues are raised in Times of India, Hindustan Times. Their regular reports are referred for this study. The city development report of each Municipal Corporation has been referred too. The Ministry of Environment and Forest (MOEF) reports related to environment status of region are referred for this study. Maharashtra Pollution Control Board has studies and provided number of reports related to environment pollution in region. We referred all the reports for this study.

\section{METHODOLOGY:}

We have calculated the Annual Compound Growth Rate (CAGR). Such method helps us to understand the change of land use for different purposes over the period of time. We have used SPSS @24 and STATA @11 for data analysis.

Compound growth rate is explained as follows

$$
\mathrm{Yt}=\mathrm{abt}
$$

Where,

Yt= Estimated land use pattern

T=year

$a$ and $b=$ parameters to be estimated

$$
\text { logyt= loga+tlogb+logut }
$$

Above equation is estimated by the ordinary least square (OLS) method then compound growth rate $(\mathrm{g})$ is then estimated by the identity given in equation as follows.

$$
g=(\hat{b}-1) * 100
$$

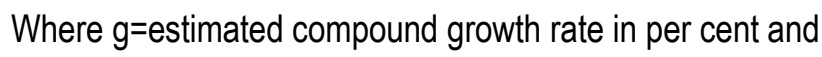




$$
\hat{b=a n t i \log b}
$$

We have used ordinary least square regression method to understand the relationship of wet lands with other subheads. In order to examine the land use pattern in different Municipal Corporation and Councils, we used the dummy variable approach method.

\subsection{Economic model:}

$$
\sum_{t=1}^{n} L=L u\left({ }_{M M R}\right)
$$

Total land available is a function of different land use pattern in Mumbai Metropolitan Region. Metropolitan Region has fixed land available for different purposes over the period of time.

$$
L u\left(_{M M R}\right)=U L B(I, S, T, U, B, K a, P, U, K h, K a r)
$$

The land use pattern in Mumbai Metropolitan Region is further divided as land use pattern in urban local bodies in Mumbai Metropolitan Region. The Urban local bodies consist of Municipal Councils, Corporations and Villages in region.

$\sum_{t=1}^{n} L u_{U L B}=(B, I, A, W, W B, O)$

The land use in urban local bodies is further divided as built up area, land for industry, Agriculture land, wetland, land under water bodies and other land.

$$
L P C_{M M R}=\sum_{t=n}^{n}\left(P o p / L_{U L B}\right)
$$

Per capita land availability to population in Mumbai Metropolitan Region is related to total population divided by land available in that urban local body.

$$
L P C_{M M R}=C(B-(W L+F L)
$$

The increase in per capita land availability in Mumbai Metropolitan Region is also related to conversion of land. The wetland and forest land is converted into built up area. Built up area is related to per capita availability of land in region.

$W L=f(E, H, O)$

Wet land is a function of environmental services in region, health of people and other functions. Other functions included as social, cultural and economic values. 


\subsection{Definition and types of wetlands:}

Wetland is commonly defined as a place where water meets land. It includes the mangroves, peat lands, rivers, lakes, deltas etc. The peat lands are defined as thick water logged soil layer made up of dead and decaying plant material. It mainly includes moors, mires, peat swamp forests and perm frost tundra. Peat lands mainly absorb heavy rainfall. It provides protection against floods and release water slowly. The rivers and deltas provides habitat for fish and animals. Man grows forests useful for protection and shelter due to extreme weather conditions near coast line. Man grows leaves and roots provide nutrients that nourish plankton, algae, fish and shellfish. The man grows are home to many birds and mammals. Arctic wetlands are useful to plants, animals and birds. Migratory birds and arctic finds indispensable breeding and feeding area. Wetlands due to their biological, ecological, social, cultural and economic values form an important component of the environment. They provide habitats and support diverse range of biodiversity. Wetland undertakes important biological and ecological processes including life support systems i.e water and carbon cycles. Hence they are important for hydrological functions, economic development, social, spiritual and cultural development (Ramachandra T.v.et.al. 2005). Wetlands are base of biodiversity in any region. They are also called as habitat nursery.

\subsection{Population growth in Greater Mumbai:}

The Greater Mumbai and suburban district is created in April 1950. Initially, an area of Mumbai suburb was $235.1 \mathrm{~km}$. The population of Mumbai suburb was 23.39 lakh in 1951. The Greater Mumbai Municipal Corporation area limit was decided at western suburbs as Jogeshwari. At eastern side, it was fixed up to Bhandup. During February 1957, the Municipal Corporation area limit is further extended up to Dahisar at western side and Mulund at central side. During 1955, Mumbai was made as capital of Maharashtra. After independence, the Parsi and Marwari people established industries and manufacturing units in city. They owned most of the industries and enterprises in city. South Indian people were involved in white collar jobs. In 1960's Nariman Point and Cuffee Parade was developed after reclamation in Arebian sea. Population of Mumbai city was increasing fast. Population in nearby suburbs was also increasing fast.

Above figure shows that during 1911, the CAGR of population in island was around 2 per cent. In 1921, the growth has slightly declined up to 1.85 per cent. In 1931, the CAGR declined and observed negative ( -0.13 per cent) of population. In 1941 , the CAGR is observed as 2.53 per cent. After independence, the growth of population took place in city. In 1951, the CAGR was 4.57 per cent of population. 


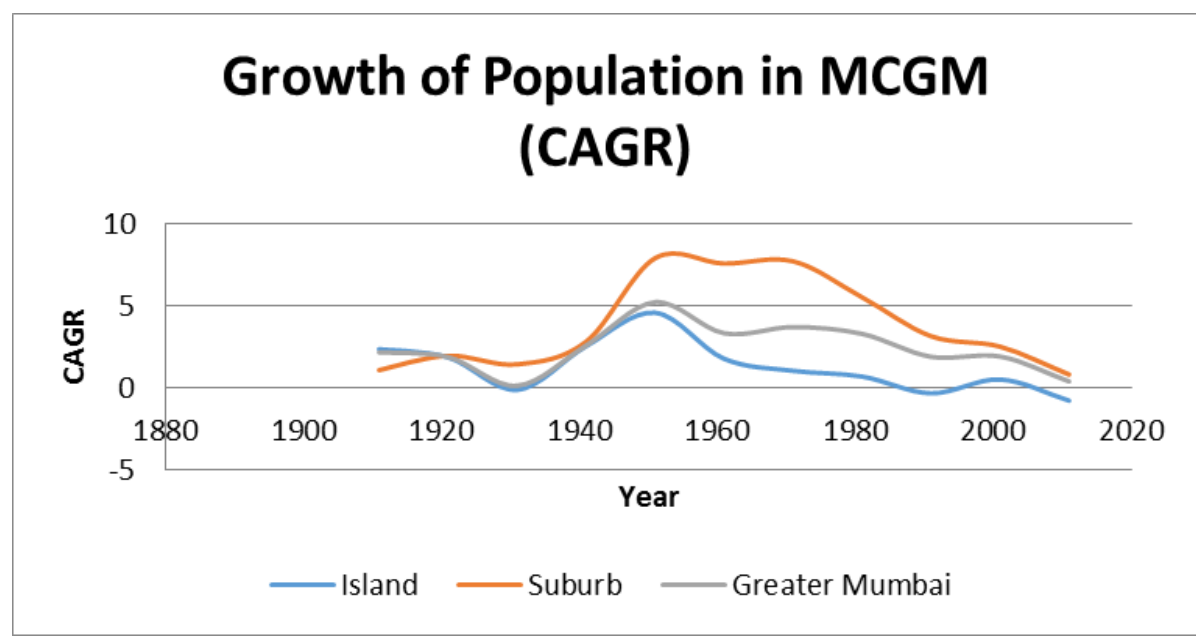

Figure 1 Population Growth In Greater Mumbai (CAGR)

Source: Population census of various years

After 1961, in island the population was continuous (1.76 per cent) decline. City was facing the area limits. Land was not available for new real estate projects. The growth of population declined and it was observed as -0.34 per cent in 1991. In 2011, the population growth was further declined and it was observed as -0.79 per cent.

From 1911 to 1931, the population growth observed very slow in suburbs. People were not ready to live in suburbs due to lack of infrastructural facilities. After 1941, the CAGR of population was observed as less than three per cent. After 1951 to 1971, CAGR was up to eight per cent. More people started preferring suburbs for living. Migration was taking place at large scale in suburbs. In 1981, the population growth rate that is CAGR was less than six per cent. In 1991, the CAGR was observed as only three per cent. In 2011, the population growth was less than one per cent. It means population was declining in suburbs in Mumbai city. Due to transport, affordable housing and amenities, people shifted to metropolitan region. We can conclude that the population growth in Greater Mumbai was two per cent in 1991. In 1941, the population growth was observed as 2.57 per cent. The population growth was very high in 1951 that is more than five per cent. In 2011, population growth has declined very fast and it was less than one per cent. We can observe that the large scale population change took place in Greater Mumbai over the period of time.

\subsection{Population growth in Mumbai Metropolitan Region:}

There was need to establish regulatory and development authority to look into developing areas and decongest Mumbai city. Therefore state government established Mumbai Metropolitan Region Development Authority (MMRDA) on 26th January 1975. It is an apex body for planning and co- 
Rode S.

WETLANDS DEGRADATION AND CONVERSION DUE TO URBANISATION IN MUMBAI METROPOLITAN REGION: ACUTE PROBLEMS WITH LONG TERM SOLUTIONS

ordination of development activities in Region for future period. Mumbai Metropolitan Region is spread over 4355 sq.km. It consists of nine Municipal Corporations such as Greater Mumbai, Thane, KalyanDombivali, Navi Mumbai, Ulhasnagar, Bhiwandi-Nizampur, Panvel, Vasai-Virar, Mira-Bhaynder. The metropolitan region has eight Municipal Councils such as Ambernath, Kulgaon-Badlapur, Matheran, Karjat, Khopoli, Pen, Uran, Alibag. It has thousand villages in Raigad and Thane district. The population growth took place all over region. The population of Mumbai city increased from 2.96 million to 4.15 million from 1951 to 1961. In 1971, the population was observed as 5.97 million. During first and second decade, the population growth was observed as 40 to 43.80 per cent respectively. In Mumbai city, the growth of population, industry, trade and commerce was observed fast. It further affected the quality of life in city. The standard of living was declining in city. Mumbai city was facing the limitation of horizontal growth due to Arabian Sea at three sides.

TABLE 1 POPULATION GROWTH AS PER MUNICIPAL CORPORATIONS AND COUNCILS (CAGR)

\begin{tabular}{|l|c|c|c|c|}
\hline Region & \multicolumn{1}{|c|}{$1971-81$} & $1981-91$ & $1991-01$ & $\mathbf{2 0 0 1 - 2 0 1 1}$ \\
\hline Greater Mumbai & 3.28 & 1.87 & 1.90 & 0.38 \\
\hline Thane & 6.45 & 5.41 & 4.62 & 3.85 \\
\hline Ulhasnagar & 5.00 & 2.74 & 2.53 & 0.66 \\
\hline KDMC & 5.99 & 6.63 & 2.55 & 1.49 \\
\hline Mira Bhaynder & 7.75 & 10.08 & 11.48 & 4.52 \\
\hline Bhiwandi & 7.13 & 6.05 & 4.68 & 1.71 \\
\hline Navi Mumbai & 8.42 & 13.09 & 8.05 & 5.32 \\
\hline Vasai virar & 2.57 & 4.16 & 6.46 & 5.80 \\
\hline Panvel & 3.37 & 4.75 & 5.84 & 5.63 \\
\hline Ambernath & 5.51 & 2.36 & 4.94 & 2.21 \\
\hline Kulgaon Badlapur & 5.50 & 4.75 & 6.51 & 5.93 \\
\hline Alibag & 1.66 & 1.49 & 1.81 & 0.62 \\
\hline Karjat & 1.13 & 2.27 & 2.37 & 1.51 \\
\hline Khopoli & 3.06 & 6.26 & 2.68 & 1.95 \\
\hline Matheran & -1.24 & 4.61 & 0.88 & -1.56 \\
\hline Pen & 2.31 & 3.87 & 3.41 & 2.28 \\
\hline \multicolumn{2}{|l|}{ Source: Population census of various years } & \\
\hline
\end{tabular}

The populations of Mumbai city started declining during 1980. The population growth declined from 3.28 per cent in 1971-81 to 0.38 per cent in 2001-11. Population in Greater Mumbai is also declined because total land area is limited and there are limitations on horizontal growth. Due to high density, lack of space and unaffordable housing, people preferred to stay in suburbs. Population growth in Thane Municipal Corporation (TMC) has declined from 6.45 per cent (1971-81) to 3.85 per cent (2001-2011). In Thane Municipal Corporation, the population growth was very high during 1971-81. In Thane city, 
large scale migration took place during this period. Now migration in city has declined because overcrowding, unaffordable housing and lack of infrastructure facilities. In Ulhasnagar Municipal Corporation (UMC), the population growth declined from 5 per cent (1971-81) to 0.66 per cent in 200111. In Ulhasnagar city, population has continuously declined after 1971-81 period. This is due to lack of urban amenities, unplanned development in city. In KDMC, the population growth was 6 per cent during 1971-81. In 2001-11, it was observed as 1.49 per cent. In Mira Bhaynder, population growth was observed as only 4.52 per cent. In Bhiwandi Nizampur Municipal Corporation, the population growth was 7.13 per cent during 1971-81. In 2001-11, population growth was only 1.71 per cent. In Bhiwandi Nizampur Municipal Corporation, population is declining due to lack of urban amenities. Direct transportation is not available to Bhiwandi city from Mumbai city. In NMMC, the population growth was 13.09 per cent during 1981-91. In 2001-2011, total 5.32 per cent population growth is observed. Population is still growing in this Municipal Corporation. In Vasai Virar Municipal Corporation, population growth in 1971-81 was only 2.57 per cent. In 2001-11, it was observed as 5.80 per cent. Many people from Western Mumbai, North India migrated to Vasai Virar due to affordable housing. In Panvel Municipal Corporation, the population growth in 1971-81 was 3.37 per cent. In 2001-11, the population growth was observed as 5.63 per cent. In Panvel, city population is increasing due to number of housing projects, railway and highway transport facility from city and proximity to Jawaharlal Nehru Port Trust (JNPT) and international airport. The employment opportunities and mobility is available in Panvel. In Ambernth Municipal Council, the population growth was 5.51 per cent during 1971-81 periods. The growth of population in 2001-11 was 2.21 per cent. In Kulgaon-Badlapur Municipal Council, population growth in 1991-2001 was 6.51 per cent. In 2001-11, it was observed as 5.93 per cent. In Alibag Municipal Council, the population growth rate has declined in 2001-11. It was observed as 0.62 per cent. In 1971-81, it was observed as 1.66 per cent. In Karjat Municipal Council, the population growth in 2001-2011 was 1.51 per cent. But in 1981-91, it was observed as 2.27 per cent. In Khopoli Municipal Council, the population growth in 1971-81 was 3.06 per cent. In 2001-11, it was observed as 1.95 per cent. In Mathran Municipal Council, the population in 1981-91, was growing with 4.61 per cent. But in 2001-11, it was observed as negative (-1.56 per cent) in terms of growth rate. In Matheran, new constructions are banned. It is an environment sensitive zone of region. The state government applied very strict norms for people those harm environment. The amenities in Matheran are low and future infrastructure projects are not planned. Therefore population growth has declined. In Pen Municipal Council, the population growth was 2.31 per cent in 1971-81. In 2001-11, it was observed as 2.28 per cent. In Uran Municipal Council, the population growth was 1.86 per cent in 1971-81. In 2001-11, it was observed as 2.73 per cent. Population in this municipal council is increasing over the period of time due to housing projects and tourism and other employment opportunities. In Uran Municipal Council, the 
Rode S.

WETLANDS DEGRADATION AND CONVERSION DUE TO URBANISATION IN MUMBAI METROPOLITAN REGION: ACUTE PROBLEMS WITH LONG TERM SOLUTIONS

housing and transportation is promoted by City Industrial and Development Corporation (CIDCO). The employment facilities are available at Jawaharlal Nehru Port Trust (JNPT) and Special Economic Zone (SEZ). Therefore people prefer to stay in Uran and it is developing very fast in Navi Mumbai.

\subsection{Land use pattern and wetland related issues in Mumbai Metropolitan Region}

Wetlands are among the most important and yet most threatened eco-systems in India. They are a precious part of our cultural and natural heritage, providing and extremely important resource for many human interest and activities, as well as habitats that support a rich diversity of animal and plant life (Biswasroy M. et.al 2011). Mumbai Metropolitan Region has 4355 sq.km area. Such area is allocated for different purposes in region. The allocation of land cannot be easily changed. There are certain laws exist to change land allocated for different purposes. But due to population and housing pressure, state government and Municipal Corporations and Councils are changing land allocation.

TABLE 2 ChANGE OF LAND USE OVER THE PERIOD OF TIME FROM 1971 TO 1991 (CAGR)

\begin{tabular}{|l|c|c|c|c|c|c|c|}
\hline Region & Built up & Industry & Agriculture & Forest & Wet land & $\begin{array}{l}\text { Water } \\
\text { Bodies }\end{array}$ & Others \\
\hline Island city & 0.72 & 1.44 & 0.00 & 0.00 & -2.14 & 0.00 & -2.16 \\
\hline Suburbs & 3.24 & 0.10 & -3.45 & -0.38 & -1.31 & -0.40 & -0.02 \\
\hline Thane & 8.71 & 5.42 & -2.79 & 0.00 & -0.24 & -0.15 & 0.00 \\
\hline Vasai & 17.22 & 0.00 & -1.31 & 0.56 & -0.06 & -1.54 & 0.00 \\
\hline Bhiwandi & 13.55 & -6.72 & -0.69 & 0.78 & 2.17 & -2.24 & 0.00 \\
\hline Kalyan & 5.74 & 16.22 & -2.17 & 2.52 & 11.03 & -1.99 & 0.16 \\
\hline Panvel & 14.36 & 9.85 & -2.73 & 4.53 & 0.47 & 0.00 & 0.00 \\
\hline Uran & 14.73 & 1.39 & -3.02 & 6.83 & -0.03 & 0.00 & 0.00 \\
\hline Khalapur & 10.26 & 0.00 & -4.36 & 3.06 & 1.91 & -1.01 & 0.00 \\
\hline Karjat & 0.58 & 0.00 & -1.32 & 1.79 & 0.00 & -0.07 & 0.00 \\
\hline Total & 4.61 & 4.36 & -1.94 & 1.82 & -0.18 & -1.14 & -0.44 \\
\hline
\end{tabular}

Source: 1971: Draft regional plan for MMR, 1971-1991, 1991: Draft regional plan for MMR, 1996-2011.

The above table shows that the build-up land has increased in Vasai (17.22 per cent), Uran (14.73 per cent) and Panvel (14.36 per cent) from 1971 to 1991. During 1971-91, the built up area in Vasai was highest because new housing projects. The state government gave permission to build housing on waste and salt pan area. The forest, agriculture and wet land was converted for built up area. In Panvel, large housing projects and commercial establishments planned in city. They are connected through high ways, local transport and airport. Therefore there was demand for housing by people in this region. 
WETLANDS DEGRADATION AND CONVERSION DUE TO URBANISATION IN MUMBAI METROPOLITAN REGION: ACUTE PROBLEMS WITH LONG TERM SOLUTIONS

Many farmers sold their land to developers. Land in Mumbai is not available for housing projects. Therefore built up land cannot be increased in city. In Uran, City Industrial and Development Corporation (CIDCO) allowed residential projects and special economic zone. The waste, forest and wet lands have brought under built up area. Many government projects are announced on public land in this suburb. In Karjat, the lowest growth of (0.58 per cent) built up area is found. The industrial area has increased in Kalyan (16.22 per cent), Panvel (9.85 per cent) and Thane (5.42 per cent). The land under industry is more in Kalyan in region. It is mainly because after independence, many large and small industries were established near Kalyan. Kalyan city is a proximate city to Mumbai therefore state government encouraged industrialisation after independence. In all suburbs of MMRDA, the land under agriculture has declined. The land under agriculture has declined significantly in Khalapur (-4.36 per cent), Suburbs (-3.45 per cent) and Uran (-3.02 per cent). The land is brought under the built up area in Khalapur. The land under forest cover has increased in Uran (6.83 per cent), Panvel (4.53 percent), Area under forest land is very high in Uran. Uran is located near coastal area of Arabian Sea. Due to climatic conditions, forest land is more in Uran. It is one corner of region. The land under wetland category was more in Kalyan (11.03 per cent) and Bhiwandi (2.17 per cent). The area under wetland has declined in island city (-2.14 per cent) and suburb (-1.31 per cent). The area under water bodies has declined in Bhiwandi (-2.24 per cent) and Kalyan (-1.99 per cent). Due to population pressure, the land under water bodies has destroyed. All the water bodies are developed as built up area. The municipal corporation is not paying adequate attention in order to protect the water bodies. Water bodies are important for biodiversity. But it has continuously ignored in region. The area under other use has declined very sharply in island city (-2.16 per cent). We can conclude that the area under built up (4.61 per cent), industry (4.36 per cent) and forest (1.82 per cent) has increased in Mumbai Metropolitan Region. The area under agriculture (1.94 per cent) and water bodies (1.14 per cent) has declined during 1971 to 1991 period.

In 1991-2011 periods, the area under built up has increased in Karjat (13.73 per cent), Uran (13.60 per cent) and Khalapur (13.31 per cent). Built up area increased in Karjat and it is followed by Uran and Khalapur. The built up area is observed as negative in suburbs. The area under built up category has declined in suburbs ( 9.23 per cent). Area under the industry is found more in Uran (19.93 per cent). It is followed by Bhiwandi. Lowest area under industry is found in Panvel city. Jawaharlal Neharu Port Trust (JNPT) is located very close to Panvel city. All the roads of Panvel connected to JNPT. Every day thousands of cargo trucks, containers traveling from Panvel to JNPT. Panvel is good place to live due to climatic conditions. 
Rode S.

WETLANDS DEGRADATION AND CONVERSION DUE TO URBANISATION IN MUMBAI METROPOLITAN REGION: ACUTE PROBLEMS WITH LONG TERM SOLUTIONS

TABLE 3 GROWTH OF LAND USE FROM 1991 vs 2011(CAGR)

\begin{tabular}{|l|c|c|c|c|c|c|c|}
\hline \multicolumn{1}{|c|}{ Region } & Built up & Industry & Agriculture & Forest & Wet land & $\begin{array}{c}\text { Water } \\
\text { Bodies }\end{array}$ & others \\
\hline Island city & 0.49 & -0.71 & 0.00 & 0.00 & -100.00 & 0.00 & 0.79 \\
\hline Suburbs & -9.83 & 2.87 & 7.69 & -100.00 & -100.00 & -0.77 & 7.13 \\
\hline Thane & 7.27 & -2.40 & -0.69 & -7.24 & -8.37 & 1.12 & 16.97 \\
\hline Vasai & 6.86 & 4.88 & 0.49 & -2.27 & -10.61 & -1.95 & 0.00 \\
\hline Bhiwandi & 9.02 & 10.78 & -0.67 & -0.40 & -14.09 & -1.78 & 0.00 \\
\hline Kalyan & 7.01 & 1.90 & 0.41 & -2.90 & -17.25 & -0.66 & -1.09 \\
\hline Panvel & 10.49 & -5.88 & -1.71 & -2.03 & -7.29 & 1.68 & 0.00 \\
\hline Uran & 13.60 & 19.93 & -6.87 & -5.66 & -2.99 & -0.36 & 7.41 \\
\hline Khalapur & 13.31 & -0.31 & 1.23 & -3.07 & -100.00 & 4.91 & 0.00 \\
\hline Karjat & 13.73 & 0.00 & -0.36 & -2.02 & -100.00 & -1.61 & 0.00 \\
\hline Total & 6.06 & 1.70 & -0.24 & -2.67 & -8.88 & 0.07 & 8.39 \\
\hline
\end{tabular}

Source: 1991: Draft regional plan for MMR, 1996-2011. 2011: Draft regional plan for MMR 1996-2011

The job opportunities are available at JNPT and surrounding area. State transport buses of different depot are passing from Panvel city. Alibag-Delhi corridor is passing from Panvel. The industrial corridor such as Taloja and Maharashtra Industrial Development Corporation area is very close to Panvel. City provides employment opportunities, residential and educational facilities, health care, water supply, sanitation to people. Therefore Panvel is growing very fast in Metropolitan region. Area under industry has increased in Uran (19.93 per cent), Bhiwandi (10.78 per cent). Bhiwandi is known as textile industry and it is power house of handloom units. The area under industry has declined in Panvel (-5.88 per cent) and Thane (-2.40 per cent). The area under agriculture has increased surprisingly in suburb (7.69 per cent). The area under agriculture has declined in Uran (-6.87 per cent) and Panvel (-1.71 per cent). The agricultural land is significantly declined in Uran. Due to high urbanization, agriculture land is declining very fast. Land is sold or rented for different purposes in this council. Many farmers left land cultivation and sold their land for different purposes. Due to number of employment opportunities, labors are not available at lower wage rate for agricultural work. The area under forest has declined hundred per cent in suburbs. The area under forest has declined in Thane (-7.24 per cent), Uran (-5.66 per cent) and Khalapur (-3.07 per cent). Forest land declined in Thane from 1991-2011. It is followed by Uran city. The wetland has declined hundred per cent and it is declined in Island, suburbs, Khalapur and Karjat. The study highlight the strong response of riverine wetlands to a wide range of human pressures, including dropping water levels, changing nutrient concentrations, rising population and intensifying agriculture (Hudon C.et. al 2018). The wetland also declined in Kalyan (-17.25 per cent) and Bhiwandi (14.09 per cent). The area under water bodies has increased in Khalapur (4.91 per cent), Thane (1.12 
Rode S.

WETLANDS DEGRADATION AND CONVERSION DUE TO URBANISATION IN MUMBAI METROPOLITAN REGION: ACUTE PROBLEMS WITH LONG TERM SOLUTIONS

per cent). Wet land is exists in island, suburbs, Khalapur and Karjat. But 1991-2011 report shows that wetland does not exist at all in suburbs. Due to high urbanization, the wetland is destroyed in these suburbs. The area under water bodies has declined in Vasai (-1.95 per cent), Karjat (-1.61 per cent). The area under other use has increased in Thane (16.97 per cent) and Uran (7.41 per cent). The area under built up ( 6.06 per cent) and industry (1.70 per cent) has increased from 1991 to 2011 . The area under wetland (8.88 per cent) has declined significantly from 1991 to 2011. The area under other use (8.39 per cent) has increased over the period of time. The land use pattern and change since 1971, 1991 , and 2011 is given in the following table1.

TABLE 4 LAND USE CHANGES IN MMR (AREA SQ.KM)
\begin{tabular}{|l|c|c|}
\hline \multicolumn{1}{|c|}{ Land use } & \multicolumn{2}{c|}{ Change of land use } \\
\hline & $1971-91$ & $91-2011$ \\
\hline Built up & 202.00 & 723.00 \\
\hline Industry & 57.00 & 38.00 \\
\hline Agriculture & -652.00 & -65.00 \\
\hline Forest & 426.00 & -592.00 \\
\hline Wetland & -12.00 & -300.00 \\
\hline Water body & -16.00 & 1.00 \\
\hline
\end{tabular}

Source: 1971: Draft regional plan for MMR, 1971-1991, 1991: Draft regional plan for MMR, 1996-2011, 2011: Draft regional plan for MMR 1996-2011

We can see that from 1971 to 1991, total 202 square kilometer (sq.km) areas have increased in built-up category. Population pressure and housing requirement forced government to convert forest and wetland into built up area. In 1991-2011, total 723 sq.km area has increased from 1991-2011. Migration is continuous process in region. More and more land is required for migrating and increasing population. Therefore more land is converted from forest, agriculture, wetland to build up land in region. The area under industry has increased as 57 square kilometer from 1971 to 1991. In 1991-2011, the area under industry has increased up to $38 \mathrm{sq}$. km. The area under agriculture declined from 1971-91 (652 sq.km). From 1991-2011, the area under agriculture declined as $65 \mathrm{sq} . \mathrm{km}$ in region. The area under forest has increased up to 426 sq.km from 1971-91. But it is observed inversely in next period. The area under forest has declined as $592 \mathrm{sq}$. $\mathrm{km}$ from 1991 to 2011. It is the highest area which has declined in Mumbai Metropolitan Region. It simply means forest land has converted for different purposes in region. Government took over forest land for different development projects in region. The area under wetland has only declined as $12 \mathrm{sq}$. km from 1971 to 1991. From 1991-2011, the area under wetland has declined as $300 \mathrm{sq.km}$. It is second highest after land under forest area. Wetland is simply converted for different purposes in region. Urbanization is increasing very fast in region. There is no choice for government but to make available more wet land for housing and other purposes. The area under water bodies has declined as $16 \mathrm{sq.} \mathrm{km} \mathrm{from} 1971$ to 1991. During 1971-91, the area under other use has 
Rode S.

WETLANDS DEGRADATION AND CONVERSION DUE TO URBANISATION IN MUMBAI METROPOLITAN REGION: ACUTE PROBLEMS WITH LONG TERM SOLUTIONS

declined as $5 \mathrm{sq}$. $\mathrm{km}$. During this period, it is minor change observed as land in other use category. The area under other use has increased as $198 \mathrm{sq} . \mathrm{km}$ from 1991-2011 periods. The area under forest and wetland has declined very sharply from 1991 to 2011 period. It is the major concern in the metropolitan region.

TABLE 5 ChANGe OF AREA SINCE 1971 TO 2011 IN MMRDA (PER CE
\begin{tabular}{|l|c|c|c|}
\hline Area & 1971 & 1991 & 2011 \\
\hline Built up & 3.87 & 9.11 & 27.86 \\
\hline Industry & 1.17 & 2.64 & 3.63 \\
\hline Agriculture & 54.43 & 37.51 & 35.83 \\
\hline Forests & 27.12 & 38.17 & 22.81 \\
\hline Wetland & 9.71 & 9.39 & 1.61 \\
\hline Water bodies & 2.16 & 1.74 & 1.77 \\
\hline Other & 1.54 & 1.42 & 6.55 \\
\hline
\end{tabular}

From the above table, we can see that the area under built up was only 3.87 per cent of total area in 1971. The built up area increased more than seven times ( 27.86 per cent) in 2011. The area under industry was 1.17 per cent of total area in 1971. It is observed as 3.63 per cent in 2011. The land under agriculture was 54.43 per cent in 1971. It was observed as only 37.51 per cent in 1991 and 35.83 per cent in 2011. It means the area under agriculture is continuously declining in region. Due to industrialization, urbanization, it is inconvenient to cultivate land for various crops in region. Labors are not available. The agriculture land is sold for different purposes by farmers. Farmers have started accepting different forms of income generating opportunities in region. The area under forest was 27.12 per cent in 1971. In 2011, it was observed as 22.81 per cent. The area under wetland was 9.71 per cent in region in 1971. It was observed as only 1.61 per cent in 2011. The area under water bodies was 2.16 per cent in 1971. In 2011, area under water bodies was only 1.77 per cent in metropolitan region. The area under water bodies has significantly declined in this period. The area under other use was 1.54 per cent in 1971. In 2011, it was observed as 6.55 per cent. We can conclude that the area under built up, industry and others has declined in region. The area under agriculture, forest, wetland, water bodies has declined over the period of time in region. As far as municipal councils and corporations in region are concerned then we can also observe same trend.

Above table clearly shows that built up area in island has declined from 1971 (30.32 per cent) to 2011 (5.29 per cent). In suburbs also, the area under built up has declined from 47.62 per cent (1971) to 1.69 per cent (2.11). 
Rode S.

WETLANDS DEGRADATION AND CONVERSION DUE TO URBANISATION IN MUMBAI METROPOLITAN REGION: ACUTE PROBLEMS WITH LONG TERM SOLUTIONS

Table 6 Change OF Land use since 1971 to 2011 (PeR CENT)

\begin{tabular}{|l|c|c|c|c|c|c|c|c|c|}
\hline \multirow{2}{*}{ Region } & \multicolumn{4}{|c|}{ Built up } & \multicolumn{3}{c|}{ Industry } & \multicolumn{3}{c|}{ Agriculture } \\
\cline { 2 - 11 } & 1971 & 1991 & 2011 & 1971 & 1991 & 2011 & 1971 & 1991 & 2011 \\
\hline $\begin{array}{l}\text { Island } \\
\text { city }\end{array}$ & 30.32 & 14.76 & 5.29 & 10.62 & 6.19 & 3.93 & 0.00 & 0.00 & 0.00 \\
\hline Suburbs & 47.62 & 37.07 & 1.69 & 35.40 & 16.03 & 19.93 & 2.28 & 1.70 & 7.28 \\
\hline Thane & 6.37 & 13.22 & 16.39 & 33.19 & 40.22 & 18.43 & 6.82 & 5.78 & 5.31 \\
\hline Vasai & 0.87 & 7.58 & 8.73 & 0.00 & 1.67 & 3.00 & 9.83 & 11.11 & 12.78 \\
\hline Bhiwandi & 1.07 & 5.10 & 8.60 & 2.21 & 0.39 & 2.00 & 21.11 & 26.88 & 24.77 \\
\hline Kalyan & 8.85 & 10.85 & 12.85 & 2.21 & 17.11 & 17.78 & 20.06 & 19.19 & 21.72 \\
\hline Panvel & 1.34 & 7.29 & 15.87 & 5.31 & 14.06 & 3.23 & 20.19 & 17.32 & 13.06 \\
\hline Uran & 0.34 & 1.94 & 7.14 & 2.21 & 1.28 & 29.35 & 6.08 & 4.92 & 1.33 \\
\hline Khalapur & 0.34 & 0.91 & 3.20 & 7.74 & 3.44 & 2.36 & 4.53 & 2.81 & 3.71 \\
\hline Karjat & 2.88 & 1.37 & 5.15 & 0.000 & 0.00 & 0.00 & 9.10 & 10.26 & 10.03 \\
\hline
\end{tabular}

Source: As per above table

State government does not allow new built up area in suburbs of region. There are no vacant spaces remained for construction in suburbs. In all other Councils and Corporations, the built up area has increased over the period of time. As far as industry is concerned then in Island, industrial area has declined from 10.62 per cent (1971) to 3.93 per cent (2011). Due to high density, rising prices of land, high wages many industries were closed in Island. In Suburbs, the industrial area has declined form 35.40 per cent (1971) to 19.93 per cent (2011). Many industries were exists in suburbs. Many workers were working at ports, cotton mills and handloom, petro-chemical, refinery industries. Most of the old industries and companies are closed and the land is sold for big residential projects in island city and suburbs. Now industries shifted to outside of Mumbai and Thane belt due to low cost of land, wages to labours, electricity charges etc. Therefore area under industry in Vasai has increased up to 3 per cent in 2011. In Kalyan, area under industry has reported as 17.78 per cent in 2011. Area under industry in Uran has also reported as 29.35 per cent in 2011. Area for industrial development is available in this region. Land under agriculture has increased in Vasai from 1971 (9.83 per cent) to 2011 (12.78 per cent). This may be because of waste land and it could have brought under the agriculture in this corporation. We can see the change in the area of wetland in region in the table below.

In Island city, forest land did not exist since 1971. Area under forest was 9.85 per cent in suburbs in 1971. But in 2011, area under forest is not found in suburbs. Due to growth of population, it has been destroyed and land used for other purposes. The area under forest in Thane was 9.37 per cent. In 2011, the area under forest was only 2.67 per cent. In Karjat, the area under forest was 10.06 per cent in 1971. But in 2011, it was observed as 11.38 per cent. Karjat is located very near Western Ghat. 
Rode S.

WETLANDS DEGRADATION AND CONVERSION DUE TO URBANISATION IN MUMBAI METROPOLITAN REGION: ACUTE PROBLEMS WITH LONG TERM SOLUTIONS

TABLE 7 ChANGe OF FOREST, WETLAND, WATER BODIES AND OTHER AREA IN REGION (PER CENT)

\begin{tabular}{|l|c|c|c|c|c|c|c|c|c|c|c|c|}
\hline & \multicolumn{4}{|c|}{ Forest } & \multicolumn{3}{c|}{ Wetland } & \multicolumn{3}{c|}{ Water bodies } & \multicolumn{3}{c|}{ Others } \\
\hline Region & 1971 & 1991 & 2011 & 1971 & 1991 & 2011 & 1971 & 1991 & 2011 & 1971 & 1991 & 2011 \\
\hline Island city & 0.00 & 0.00 & 0.00 & 2.38 & 1.63 & 0.00 & 0.00 & 0.00 & 0.00 & 25.21 & 18.10 & 4.55 \\
\hline Suburbs & 9.85 & 6.51 & 0.00 & 33.69 & 27.10 & 0.00 & 11.39 & 13.11 & 11.17 & 36.13 & 39.12 & 31.35 \\
\hline Thane & 9.37 & 6.66 & 2.67 & 20.17 & 19.92 & 22.13 & 4.20 & 5.07 & 6.17 & 2.52 & 2.74 & 11.68 \\
\hline Vasai & 17.22 & 13.60 & 14.72 & 11.84 & 12.10 & 8.40 & 5.16 & 4.77 & 3.23 & 0.00 & 0.00 & 9.78 \\
\hline Bhiwandi & 19.13 & 15.77 & 24.46 & 6.68 & 10.39 & 3.39 & 19.18 & 15.50 & 10.87 & 0.00 & 0.00 & 10.09 \\
\hline Kalyan & 16.38 & 18.66 & 17.86 & 0.27 & 2.02 & 0.32 & 29.50 & 25.04 & 21.75 & 26.89 & 30.16 & 5.30 \\
\hline Panvel & 9.76 & 16.10 & 18.22 & 8.55 & 9.67 & 13.41 & 14.39 & 17.88 & 24.18 & 0.00 & 0.00 & 13.32 \\
\hline Uran & 1.91 & 4.77 & 2.64 & 15.50 & 15.94 & 52.34 & 1.80 & 2.24 & 2.06 & 9.24 & 10.05 & 8.47 \\
\hline Khalapur & 6.31 & 7.95 & 7.36 & 0.80 & 1.19 & 0.00 & 4.80 & 4.92 & 12.05 & 0.00 & 0.00 & 4.12 \\
\hline Karjat & 10.06 & 10.03 & 11.38 & 0.13 & 0.14 & 0.00 & 9.59 & 11.77 & 8.52 & 0.00 & 0.00 & 1.35 \\
\hline
\end{tabular}

Source: Above table

It is environmentally sensitive and protected region. The climatic conditions are favorable for the growth of forest. The area under wetland was 33.69 per cent during 1971 in Suburbs. In 2011, the area under wetland is not found in suburbs. There is total decline in the forest area in suburbs. In Thane city, the area under wetland in 1971 was 20.17 per cent. In 2011, the area under wetland was 22.13 per cent. In Uran, area under wetland was 52.34 per cent in 2011. It is a Municipal Council where more than half of the area is under the wetland. In Uran, maximum wetland was exists but now the debris are dumped in Dronagiri node of Uran Taluka. Such debris is destroying hundred hectors of mangroves. Mangroves provide valuable ecosystem services for the wellbeing of coastal communities (Rahman M. M. 2018). It has been observed that the dumpers and JCB continuously move in Uran taluka as construction are going on for numerous housing projects. CIDCO is not taking measures to protect wetlands in Uran. Dronagiri is an emerging node for residential purpose and it is a part of international airport area. There are many wetland zones in Uran. But they have been reclaimed for various development projects. Many hectures of wetland has been lost for big government projects such as Jawaharlal Nehru Port Trust (JNPT), Oil and Natural Gas Corporation (ONGC) and Navi Mumbai International Airport. Road widening work is going on in Uran. The construction of a port and jetty area destroyed mudflats that are homes to wetland birds including flamingos. Area under wetland has completely destroyed in Khalapur and Karjat as per 2011 data. The wetland area contributes to several quality-of-life aspects, such as encountering nature and experiencing beauty. The areas also facilitate activities that support well-being to have high restorative qualities (Pedersen E.et.al 2019). But all the aspects are not accepted in these municipal councils of region. The area under water bodies in Panvel was 14.39 per cent in 1971. In 
Rode S.

WETLANDS DEGRADATION AND CONVERSION DUE TO URBANISATION IN MUMBAI METROPOLITAN REGION: ACUTE PROBLEMS WITH LONG TERM SOLUTIONS

2011, the area under water bodies was found as 24.18 per cent. In Khalapur, the area under water bodies was 4.80 per cent in 1971. But in 2011, the area under water bodies was 12.05 per cent. The area under other category has increased in Thane from 1971 (2.52 per cent) to 2011 (11.68 per cent). Since 1971, large area of land is converted for different purposes in region. The forest, wetland, land under water bodies has converted to build up area in all municipal councils and corporations in region.

TABLE 8 CONVERSION OF DIFFERENT LAND USES TO BUILD UP AREA IN MMR (SQ. KM)

\begin{tabular}{|l|c|c|c|c|}
\hline \multirow{2}{*}{ Converted land } & \multicolumn{2}{c|}{$1971-91$} & \multicolumn{2}{c|}{ 1991-2011 } \\
\cline { 2 - 5 } & Area & Per cent & Area & Per cent \\
\hline Industry & 1 & 0.5 & 2 & 0.3 \\
\hline Agriculture & 137 & 63.9 & 57 & 7.9 \\
\hline Forest & 28 & 13.1 & 388 & 54.1 \\
\hline Wetlands & 41 & 18.9 & 244 & 33.9 \\
\hline Water body & 4 & 1.4 & 6 & 0.8 \\
\hline Others & 5 & 2.2 & 22 & 3 \\
\hline
\end{tabular}

Source: 1971: Draft regional plan for MMR, 1971-1991, 1991: Draft regional plan for MMR, 1996-2011, 2011: Draft regional plan for MMR 1996-2011

Above table shows that the area for industry was converted one square kilometer during 1971-91. But in 1991-2011, it was made double. The 137 sq.km area under agriculture was converted during 1971-91. But during 1991-2011, it was found as only $57 \mathrm{sq} . \mathrm{km}$. Such areas were converted for other purposes. Total 28 sq.km area under forest was converted for different purposes. But in 1991-2011, total 388 sq. km area was converted of forest for other purposes. The area under wetland during 1971-81 was converted for different purposes. The $244 \mathrm{sq} . \mathrm{km}$ area under wetland in 1991-2011 was converted for different purposes. It means total $622 \mathrm{sq} . \mathrm{km}$ area of forest and wetland in region is converted for different purposes in region. These two components are affected from land conversion since 1971. Thane, Kalyan and Uran suburbs are growing fast in terms of population. In Uran, growth of population is observed very high in recent period. In current year, twenty hectares of mangroves removed by PSUs for development projects. The villages in Uran are most affected such as such as Gavhan, Hanuman Koliwada, Belpada. Total one thousand six hundred and thirty families affected due to mangroves destroyed. Mangroves are important because they act as buffer zone between the land and sea. The green cover protects the land from erosion and stands as a protector of shorelines against cyclones and ecological disasters. Wetland is breeding ground for a variety of marine animals such as invertebrates, fish, amphibians, reptiles and birds. Mangroves are good source of timer, fuel and fodder. Mangroves also absorb impurities such as harmful heavy metals and pollutant in the air. The wetlands in navy Mumbai attract a large number of migratory birds every winter. Urbanization is increasing fast in urban. Loss of common property is observed at different sites in Uran. The earlier cultivation of crops is not 
Rode S.

WETLANDS DEGRADATION AND CONVERSION DUE TO URBANISATION IN MUMBAI METROPOLITAN REGION: ACUTE PROBLEMS WITH LONG TERM SOLUTIONS

feasible due to pollution and environmental degradation. The fishing was common earlier but now fish population has declined very fast. Due to which fishermen have lost their livelihood. Small fishermen left their fishing and joined the daily wage laborer in region. Due to port, airport, the commercial infrastructure is established in region. The infrastructure has a commercial interest. The land for big projects is mainly taken from small cultivators, salt producers and fishermen's of different villages. The affected people due to number of projects are small cultivators, agriculture laborers, salt pan workers, tenants, share croppers, artisans, fisher folk etc. Environmental pollution and degradation is responsible for loss of livelihood in villages in Uran. Significant growth in population in Thane, Kalyan and Panvel region is attributed because industrialization and affordable housing projects. The built up area has increased at the cost of agriculture, forest and wet land in Mumbai Metropolitan Region. Mumbai Metropolitan Region has published new draft as regional plan for region. In this report, the following land use pattern is provided in region.

TABLE 9: LAND USE DISTRIBUTION IN MMR 2016

\begin{tabular}{|l|c|c|}
\hline \multicolumn{1}{|c|}{ Category } & $\begin{array}{c}\text { Area } \\
\text { (sq.km) }\end{array}$ & $\begin{array}{c}\% \\
\text { share }\end{array}$ \\
\hline $\begin{array}{l}\text { Agriculture and other primary } \\
\text { activities }\end{array}$ & 1307.38 & 30.32 \\
\hline Built up & 697.01 & 16.17 \\
\hline Airport & 6.15 & 0.14 \\
\hline Industry & 88.02 & 2.04 \\
\hline Port/jetty & 6.12 & 0.14 \\
\hline Wetlands & 304.07 & 7.05 \\
\hline Forest & 833.08 & 19.32 \\
\hline Scrubland/Grassland/wasteland & 889.62 & 20.63 \\
\hline Water bodies & 180.30 & 4.18 \\
\hline Total & 4311.75 & 100 \\
\hline
\end{tabular}

Source: Draft regional plan for MMR report 2016

The regional development plan shows the recent proposed land use for different purposes in region. The area under agriculture and other primary activities is shown as 30.32 per cent of total area. The built up area is kept as only 16.17 per cent. It is the planned land for built up area in region. The land under airport is 0.14 per cent. Airport is located at Santa Cruz and it is under suburbs of region. The new airport is developed near Panvel but it is under construction now. This report does not add the land under new airport. The area under industry is 2.04 per cent of total area. The area under port /jetty is kept as 0.14 per cent of total area. The wetland is considered as 7.05 per cent of total area. It means area under wetland is reserved much higher of total area in region. The area under forest is kept as 19.32 per cent in development plan. The Scrubland/grassland/wasteland is 20.63 per cent of the total area. The water bodies' area is only 
Rode S.

WETLANDS DEGRADATION AND CONVERSION DUE TO URBANISATION IN MUMBAI METROPOLITAN REGION: ACUTE PROBLEMS WITH LONG TERM SOLUTIONS

4.18 per cent of total area in Mumbai Metropolitan Region. The Mumbai Metropolitan Regional plan 2016 has given the following categories of land use pattern as per urban local bodies2.

TABLE 10: LAND USE PATTERN AS PER LOCAL BODIES IN MMR, 2016

\begin{tabular}{|l|c|c|c|c|c|c|c|c|c|c|}
\hline \multicolumn{1}{|c|}{ Area } & Agriculture & $\begin{array}{c}\text { Built } \\
\text { up }\end{array}$ & $\begin{array}{c}\text { Air- } \\
\text { Port }\end{array}$ & $\begin{array}{c}\text { Wet } \\
\text { Land }\end{array}$ & Forest & Industry & Port & $\begin{array}{c}\text { Grass } \\
\text { land }\end{array}$ & $\begin{array}{c}\text { Water } \\
\text { bodies }\end{array}$ & $\begin{array}{c}\text { Total } \\
\text { area }\end{array}$ \\
\hline $\begin{array}{l}\text { Greater } \\
\text { Mumbai }\end{array}$ & 9.18 & 48.07 & 100 & 44.93 & 24.07 & 44.74 & 100 & 20.55 & 27.69 & 33.49 \\
\hline Thane & 10.23 & 8.32 & 0.00 & 9.17 & 18.25 & 6.53 & 0.00 & 7.07 & 13.42 & 10.15 \\
\hline KDMC & 13.15 & 70.66 & 0.00 & 1.35 & 0.23 & 8.51 & 0.00 & 19.04 & 9.18 & 8.32 \\
\hline Vasai Virar & 43.72 & 10.93 & 0.00 & 18.93 & 29.23 & 10.1 & 0.00 & 17.49 & 21.22 & 21.11 \\
\hline Navi Mumbai & 1.92 & 9.21 & 0.00 & 12.07 & 8.3 & 14.58 & 0.00 & 6.31 & 6.14 & 7.81 \\
\hline Mira- Bhaynder & 9.63 & 3.83 & 0.00 & 13.04 & 7.9 & 0.61 & 0.00 & 3.42 & 16.96 & 6.78 \\
\hline $\begin{array}{l}\text { Bhiwandi } \\
\text { Nizampur }\end{array}$ & 2.73 & 2.97 & 0.00 & 0.01 & 0.47 & 1.00 & 0.00 & 2.18 & 1.05 & 1.96 \\
\hline Ulhasnagar & 0.14 & 2.13 & 0.00 & 0.00 & 0.00 & 1.71 & 0.00 & 0.51 & 0.45 & 0.95 \\
\hline Ambernath & 1.45 & 2.14 & 0.00 & 0.00 & 0.74 & 7.66 & 0.00 & 9.26 & 0.45 & 2.63 \\
\hline $\begin{array}{l}\text { Kulgaon } \\
\text { Badlapur }\end{array}$ & 4.57 & 1.62 & 0.00 & 0.00 & 2.39 & 1.45 & 0.00 & 5.75 & 1.83 & 2.57 \\
\hline Karjat & 0.76 & 0.46 & 0.00 & 0.00 & 0.14 & 0.02 & 0.00 & 1.56 & 0.28 & 0.53 \\
\hline Matheran & 0.00 & 0.17 & 0.00 & 0.00 & 3.19 & 0.00 & 0.00 & 0.04 & 0.04 & 0.54 \\
\hline Khopoli & 1.58 & 0.89 & 0.00 & 0.01 & 5.01 & 2.91 & 0.00 & 5.48 & 0.37 & 2.15 \\
\hline Panvel & 0.06 & 0.53 & 0.00 & 0.01 & 0.00 & 0.00 & 0.00 & 0.32 & 0.377 & 2.15 \\
\hline Uran & 0.21 & 0.22 & 0.00 & 0.13 & 0.11 & 0.00 & 0.00 & 0.27 & 0.56 & 0.27 \\
\hline Pen & 0.61 & 0.53 & 0.00 & 0.00 & 0.01 & 0.00 & 0.00 & 0.73 & 0.03 & 0.17 \\
\hline Alibag & 0.08 & 0.32 & 0.00 & 0.4 & 0.00 & 0.00 & 0.00 & 0.04 & 0.13 & 0.18 \\
\hline
\end{tabular}

Source: Draft regional plan for MMR report 2016

The urban local bodies have different allocation of land for different purposes. The Vasai Virar (43.7 per cent), KDMC (13.15 per cent), Thane (10.23 per cent) has kept more land under agriculture. The KDMC (70.66 per cent), Greater Mumbai (48.07 per cent), Vasai Virar (10.93 per cent) has more land under built up area. The airport is located at Santa Cruz in Grater Mumbai. The wetland is found in Greater Mumbai (44.93 per cent), Vasai Virar (18.93 per cent) and Mira Bhaynder (13.04 per cent). Forest land is 29.23 per cent of total land in Vasai-Virar. It is slightly lower in Greater Mumbai (24.07 per cent) and Thane (18.25 per cent). The land use for industry is more in Greater Mumbai (44.74 per cent), Navi Mumbai (14.58 per cent) and Khopoli (2.91 per cent). The area under port in Mumbai is hundred per cent. Since long period of time, the area is reserved for port in Mumbai. The grass land in Greater Mumbai is 20.55 per cent. It is 19.04 per cent in Kalyan and Dombivali Municipal Corporation. The land use for water bodies is found in Greater Mumbai (27.69 per cent), Thane (13.42 per cent), Vasai Virar 
Rode S.

WETLANDS DEGRADATION AND CONVERSION DUE TO URBANISATION IN MUMBAI METROPOLITAN REGION: ACUTE PROBLEMS WITH LONG TERM SOLUTIONS

(21.22 per cent), Mira Bhayaner (16.96 per cent). The area of Greater Mumbai is 33.49 per cent of total area in Mumbai Metropolitan Region3. The Mumbai Metropolitan Region has different natural species and various wetlands. All species are tolerant to some degree of disturbance, with particular species occurring at highest density in intensely disturbed habitat. Species are generally more tolerant to disturbance in larger swamps (Donaldson L. et.al 2016). The fresh water wetland has 90 species of plant. There are 88 species of fish, 7 species of mammals, 120 bird species, and 15 species of herpeto fauna. Most of the species and birds are vanishing due to decline in wetland. But still there are 22 species of reptiles in region. There are 13 species of snakes, one lizard species, one crocodile and 7 species of teratins and turtle as per the current report. All the natural species require sustainable wetland in region to survive and grow. But high pressure of urbanization is reducing the size and number of wetlands in region.

\subsection{Regression results}

In order to study the relationship of different variables with the wetland in region, we have used ordinary least square regression model. We have used secondary data of wetlands in region4. The regression model is defined as follows.

$$
\text { Yit }=\propto+\beta \times 1+\beta \times 2+\beta \times 3+\beta \times 4+
$$

Where Yit is the dependent variable and it is considered as wetland in square kilometer of region over the period of time. The independent variables are considered as the population, solid waste, sewage, land under built up area, forest, industry, wetland, water bodies, other areas. We have also used the dummy variable approach to understand effects on wetlands area in suburbs and land utilization pattern. The results are presented in the following table.

TABLE 11 REGRESSION RESULT AS PER LAND USE

\begin{tabular}{|c|c|c|}
\hline Variables & Co-efficient (std.error) & $T$ test \\
\hline Solid waste & $-0.00^{*}(0.00)$ & -4.53 \\
\hline Agriculture & $-0.03^{*}(0.00)$ & -13.72 \\
\hline Water bodies & $2.66^{*}(0.09)$ & 27.80 \\
\hline Others & $-1.52^{*}(0.00)$ & -2568.79 \\
\hline Constant & $317.52^{*}(3.10)$ & 102.42 \\
\hline
\end{tabular}

In Mumbai Metropolitan Region, population is increasing fast. The population required various daily commodities for consumption such as vegetables, newspapers, stationary, electric goods. They buy different commodities from market. Most of the commodities are either packed or provided in plastic 
WETLANDS DEGRADATION AND CONVERSION DUE TO URBANISATION IN MUMBAI METROPOLITAN REGION: ACUTE PROBLEMS WITH LONG TERM SOLUTIONS

bags. Every day all households generate solid waste in region. It is expected that the households will segregate the dry and wet solid waste in house itself. But it is not segregated at household level and maximum solid waste is thrown at public places, rivers, ponds, outside of roads, in water and man grows. The solid waste thrown at ponds and rivers harms the animals, species and birds. The livelihood of animals, fish, birds are depending on the wetlands, ponds and other fresh water sources. The polluted water in region severely effects on their livelihood, health, food and reproduction. Most of the fish and birds die regularly due to unhygienic conditions at wetlands in region. People avoid visiting such places due to unhygienic conditions and uncollected solid waste and sewage flow. Even though thousands species are depending on wetland for survival, government is not paying any attention on their conservation. Such wetlands are filled with debris in region and converted that land for different purposes. Land is very scarce in region and urbanization is growing fast. Therefore filling wetlands with debris and cutting mangroves is the only option to make the land available for different purposes. The solid waste is also dumped at different landfill sites in region. Agriculture land in region is negatively corelated with wetlands in region. In region, land under agriculture is continuously declining. In region, land was under agriculture and farmers were cultivating land. But due to high educational and employment opportunities and carrier achievements, the income opportunities have increased. Few farmers have changed the allocation of land. Government took over the land for different purposes in region. Large scale urbanization is taking place in Vasai Virar, Ulwe and Panvel where farmers land is acquired by the builders for construction purposes. They changed the allocation of agriculture land to build up and industrial area. The conversion of agricultural land could be taking place because built up and industrial land has better returns for farmers. The agriculture land in region is simply used for cultivation for food grains only. The state government has kept reserve land under water bodies such as ponds, rivers, lakes. Such water bodies help species, birds and reptiles to grow. They find food and survivals near and in water bodies. Therefore land under water bodies is positively co-related to wetlands in region. Land under other use is negatively co-related with wetlands. Government has taken over the land for different purposes. Over the period of time, the land is taken for various development projects and infrastructure in region. Due to urbanization, population is increasing fast in all suburbs of region. An extra population required more space which includes housing, roads, parking, gardens etc. Therefore new markets, educational institutions, gardens, roads, railway network, housing are developed in suburbs of region. The land is continuously transferred under the other purposes. Therefore it is negatively co-related with land under wetlands in region. We have used the dummy variable approach to understand the difference of land use pattern in suburbs in region. Every suburb is different from each other in terms land availability, biodiversity, population and amenities. The result of such regression is presented in the following table. 
Rode S.

WETLANDS DEGRADATION AND CONVERSION DUE TO URBANISATION IN MUMBAI METROPOLITAN REGION: ACUTE PROBLEMS WITH LONG TERM SOLUTIONS

TABLE 12 REGRESSION RESULTS AS PER USE OF LAND IN SUBURBS

\begin{tabular}{|l|c|c|}
\hline \multicolumn{1}{|c|}{ Variables } & Co-efficient (std.error) & T test \\
\hline Built up & $-0.18^{*}(0.01$ & -15.86 \\
\hline Industry & $-0.43^{*}(0.03)$ & -17.15 \\
\hline Agriculture & $-0.40^{*}(0.17)$ & -23.45 \\
\hline Forest & $-0.17^{*}(0.02)$ & -11.20 \\
\hline Water bodies & $1.51^{*}(0.10)$ & 14.15 \\
\hline Others & $-1.71^{*}(0.02)$ & -79.89 \\
\hline Islands & $-195.97^{*}(9.60)$ & -20.40 \\
\hline Suburbs & $-42.04^{*}(7.32)$ & -5.74 \\
\hline Thane & $-100.16^{*}(6.12)$ & -16.37 \\
\hline Vasai-Virar & $-63.55^{*}(4.18)$ & -15.22 \\
\hline Kalyan & $-42.08^{*}(2.60)$ & -16.17 \\
\hline Panvel & $-32.79^{\star}(3.47)$ & -9.43 \\
\hline Uran & $-115.11^{\star}(8.07)$ & -14.26 \\
\hline Khalapur & $-177.56^{*}(8.49)$ & -20.92 \\
\hline Karjat & $-143.57^{*}(6.44)$ & -22.31 \\
\hline Constant & $230.99^{*}(10.52)$ & 21.96 \\
\hline
\end{tabular}

*Significant at 1 per cent

Above table shows that the built up area is negatively co-related to wet land in region. The area under industry is negatively co-related to wetland. Land under agriculture is negatively co-related to wetland in region. Area under water bodies is positively co-related to wetland. The other area in region is negatively co-related to wetland in Mumbai Metropolitan Region. The island in region has negative relationship with the wetland in region. The suburbs have negative relation-ship with the total wetland in region. Due to population pressure, the wetlands are already destroyed in suburbs. Thane city has negative co-relation with wetland in region. In Thane population has increased very fast over the period of time. Now population has no amenities and infrastructure facilities exits. Wetlands are destroyed for housing projects. Vasai Virar suburb has negative relationship with wetland area. The waste land, wetlands, forest land is converted for big housing projects. City is expanding very fast and it provides basic amenities of many people. Kalyan has negative co-relationship with wetland. Municipal corporation is not taking care of wetlands. Few wetlands are shrinking automatically. They are not maintained in a sustainable way. Panvel city has negative co-relationship with wetland. Panvel is growing very fast because it is well connected through local train to Thane, Andheri and CSMT. People travel to all suburbs from Panvel. Mail trains are available to Kokan, South and North India. Every day many people across the country travel from Panvel station. International airport is coming up near Panvel. People in this region are connected to whole world within short period of time. Urbanization is growing fast in Panvel. Mumbai Pune express way and old Highway is starting from Panvel. Panvel is well connected through road to Pune, Satara, Kolhapur and Bangalore. Every day thousands of people are travelling on Sion-Panvel highway. Uran has negative co-relation co-efficient with wet land in region. 
Rode S.

WETLANDS DEGRADATION AND CONVERSION DUE TO URBANISATION IN MUMBAI METROPOLITAN REGION: ACUTE PROBLEMS WITH LONG TERM SOLUTIONS

Land in Uran is mainly seen as forest, grassland, community land, etc. It is provided the base for livelihood diversification as well as critical non monetized inputs for farming and daily survival. The common property resources also constituted as essential component of interdependent ecosystem based economic activities such as livestock, fishing, salt production etc. In Uran, control over and access to land varies across different seasons and with variation with ecology. In Uran, since long period of time the land was given for cultivation to advises during the monsoon. It has been observed over one and half year, flamingos have winged away from their usual stop at mudflat and mangroves. In Uran, work of Jetties, cargo terminals, roads at JNPT is going on. Uran has already lost its entire flamingo habitat which was natural choice. Wetland birds are being squeezed into smaller areas. Fisherman reported large scale environmental degradation due to urbanization. Mangrove destruction by blocking tidal channels and reclaiming wetlands is already took place. Over the past five years, it has estimated that more than thousand hectares of man grows and wetlands have either been destroyed or dried up for construction by JNPT. The figure of wetlans destruction could be more than twenty thousand hectares in the four villages. The scale of destruction is huge. Each family has lost too much amount of money since many years. The natural environment has turned barren. Hundreds of acres of man grows are being killed by dumping debris in Uran taluka. The urbanization has paralyzed the lives of fishing community in Uran. Wetland is a natural source to combat pollution and heat and act as bulwark against floods. These valuable wetland and other natural resources need to be restored. This kind of senseless development will displace the local fishing community and destroy the ecological diversity. The Khalapur has negative co-relation with the wetland in region. The Karjat city has negative co-relation with wet land in region. We have seen that in both the suburbs, the wetlands are completely destroyed. Such wetland destructions have long term effects on communities in suburbs.

\subsection{Loss due to destruction of wetlands in Metropolitan Region}

Wetlands are among the most valuable biomes on our planet providing important ecosystem services such as nutrient cycling, soil formation and wastewater treatment (Saaltinka Rémon M. et.al 2018).They are often considered as nature-based solutions that can provide a multitude of services of great social, economic and environmental value to humankind. Changes in land-use, water-use and climate can all impact wetland functions and services. These changes occur at scales extending well beyond the local scale of an individual wetland (Thorslunda J. et.al.2017) we have calculated the wetland related loss in the Mumbai Metropolitan Region. The study of Schuyt Kirsten and Luke Brander (2004) has given the annual value of wetland function derived from one hector of wetland 5 . We have developed methodology 
Rode S.

WETLANDS DEGRADATION AND CONVERSION DUE TO URBANISATION IN MUMBAI METROPOLITAN REGION: ACUTE PROBLEMS WITH LONG TERM SOLUTIONS

to measure the wetland related services and loss occurred every year to Metropolitan Region. Such methodology is explained in the following table.

$$
\sum_{t=n}^{i=n} W M L_{M M R}=\frac{\sum_{t=1}^{i=n}\left(W l_{M M R}-T l_{M M R}\right) * M v^{*} D^{*} M_{C v}}{M}
$$

Where

WML: Monetary loss due to wetland destruction in MMR

WL: Total wetland area in MMR in square kilometer

TI: Total loss of wetland occurred in the current period

Mv: Reference median value of wetland loss

D: The current value per hector loss in US dollar

Mcv: Current exchange rate of US dollar with Indian Rupees

$M$ : Total months that is twelve in a year

We have made an attempt to estimate the loss due to wetland destruction in region. Every year around 20 per cent wetland is destroyed in region. We have calculated loss in region due to wetland destruction.

TABLE 13 TOTAL LOSS OF WETLAND IN MMR (RS. CRORE)
\begin{tabular}{|l|c|c|}
\hline Items & $1971-91$ & $1991-2011$ \\
\hline Flood control & 406.46 & 10161.60 \\
\hline Recreation fishing & 327.62 & 8190.60 \\
\hline Amenity / recreation & 430.99 & 10774.80 \\
\hline Water filtering & 252.29 & 6307.20 \\
\hline Biodiversity & 187.46 & 4686.60 \\
\hline Habitat nursery & 176.08 & 4401.90 \\
\hline Recreational hunting & 107.75 & 2693.70 \\
\hline Water supply & 39.42 & 985.50 \\
\hline Raw materials & 39.42 & 985.50 \\
\hline Fuel wood & 12.26 & 306.60 \\
\hline Total & 1979.76 & 49494.00 \\
\hline
\end{tabular}

We have estimated that flood in MMR could have caused loss of Rs.406.46 crore during 1971-91. The flood during 1991-2011 caused loss of Rs.10161.60 crore. Normally the reef mangroves and saltmarshes acts as frontline defenses against flood cycle. The root of wetland plants binds the shoreline together. It resists erosion by wind and waves. It provides physical barrier and shows down 
Rode S.

WETLANDS DEGRADATION AND CONVERSION DUE TO URBANISATION IN MUMBAI METROPOLITAN REGION: ACUTE PROBLEMS WITH LONG TERM SOLUTIONS

storm surges and tidal waves. It is reducing height and destructive power of waves. Wetlands store carbon in plants and soil. Such carbon is kept out of carbon and it helps to regulate climate. In metropolitan region, every year flooding occurs because impervious surfaces contribute erosion, flashy flows and increase in sediments loads in nearby streams. Wetlands are natural sponges in region. They soak up and hold water until it can infiltrate into the ground. If the water does not infiltrate into groundwater then it is slowly released into nearby streams. Such slow release helps to prevent flooding during storms. Vegetation in wetlands helps to reduce the speed of water. It flows over the landscape. Wetlands provide benefits of storage as well as slowing water speed. It reduces the height of floods and erosion of land. Grass lands alongside river basins acts as sponges, absorbing rainfall and controlling its flow into streams and rivers. But the mangroves, grass lands are destroyed systematically in region. Many fishermen depend on fishing in Metropolitan Region. Certain fishing species required wetlands as spawning grounds. It is nursery areas for young fish. Many species leave open water to spawn in shallow water wetlands. When plants die, the leaves and stems break down in the water. It gets form small particles of organic materials. It is called as detritus and enriched material in the principal food for many small aquatic invertebrates, various shell-fish and forage fish. It is food for larger predatory fish. Such large fish are consumed by people in region. It is a regular cycle exists in any wetland. Such cycles are also exists in various wetlands of region. All the Wetlands are fish habitat in region. They provides spawning, nursery, feeding habitat for fish. Due to cold springs and discharge of water, it lowers the temperature of the surface water. But wetland is lost in region and it caused Rs.327.62 crore loss during 1971-91. In 1991-2011 periods, the wetland related fishing declined and it costs as much as Rs.8190.60 crore. We have not calculated the health benefits after eating fish to people of region. Regular fish eating certainly improves health of people. It further improves their productivity and income. Wetland provides the water fowl, hunting, bird watching, fishing, hiking and nature observation in any region. The kids and young and old people have a propensity to want to frolic and play in wetlands. Wildlife viewing, birding is enjoyed by many people and especially in Uran. Every year thousands of birds are coming from different countries in Uran, Panvel area. People spend money on viewing and photographing wetland dependent wildlife. But there is decline in wetland area in suburbs. Total loss due to recreation during 1971-91 was Rs.430.99 crore. In 1991-2011, the loss due to wetland recreation was Rs. 10774.80 Crore. Wetlands are called as natural filters. Nitrogen in water is transformed to harmless nitrogen gas. The nutrients are taken up by wetland plants in water. Wetlands remove water pollutants such as phosphorous, heavy metals and toxins. Wetlands acts like giant sponges absorbing and holding vast quantities of water and releasing it slowly. Water gathers in wetlands and spring rains and flows gradually into nearby streams and rivers. The water is also held back by wetlands. It helps to keep water levels up in rivers and ponds during the dry summer. Wetlands help maintain surface water 
Rode S.

WETLANDS DEGRADATION AND CONVERSION DUE TO URBANISATION IN MUMBAI METROPOLITAN REGION: ACUTE PROBLEMS WITH LONG TERM SOLUTIONS

supplies by increasing the amount of water remaining in reservoirs during dry periods. But these water filters are destroyed and it costs to region. During 1971-91, its cost could be Rs.252.29 crore. In 19912011, the loss might be around Rs.6307.20 Crore to region.

Wetlands support water birds, fish, amphibian, reptiles and plant species during important life stages. Such costs cannot be measured. Wetlands are providing roosting, nesting, and feeding habitat as well as refuge during extreme weather conditions. Wetlands are corridor or steeping stone habitats that support the migration of species. It includes water birds and marine mammals. Many birds migrate regularly from Russia and other countries in suburbs. Healthy biodiversity provides essential services to environment as well as communities. It provides and purifies water. It is acting as spawning and nursery grounds for fish. It provides a refuge for animals in times of drought and it is providing recreational, cultural and spiritual benefits to people in surrounding areas. But during 1971-91, the loss due to biodiversity destruction could be Rs.187.46 crore. We have also estimated the loss during 1991-2011 as Rs. 4686.60 crore due to biodiversity destruction.

Wetlands are natural habitat nursery in different suburbs of region. The Fish, ells some lobsters, blue crabs do have distinct juvenile habitats. Nursery supplies higher percentage of species to adult sites. Identification and subsequent management of nursery habitats are important in supporting off shore fisheries and ensuring species survival into the future. But wetlands in Metropolitan Region are unable to preserve nursery habitats, recruitment of juveniles into adults. Water pollution is too much in region. It is reducing population numbers and compromising the survival of species for biodiversity and human harvesting. During 1971-91, the region could have lost Rs.176.08 crore due to loss of nursery habitat in region. During 1991-2011, the loss due to destruction of habitat nursery could be Rs. 4401.90 crore. Many people go for hunting near to wetland. They hunt different animals, birds near wetland. The forested wetlands provide an important timber resource, and seasonally dry herbaceous wetlands can be grazed. However, wetland types differ in some ecosystem functions and services because of differences in landscape position, water sources, and hydrodynamics (Steven D. and Lowrance R. 2011) Hunting at wetland would have cost of Rs. 107.75 crore during 1971-91 period. We have also estimated such cost during 1991-2011 and it was estimated as Rs.2693.70 crore.

In Mumbai Metropolitan Region, drinking water is provided through various dams. But some people depend on groundwater pumped from private wells. Pumping large quantities of water from water supply wells can draw water from the river down into the aquifer and into the well in process. It is called as induced filtration. Wetlands play a maintaining river flows during dry spells contributes to the amount of water available for use by people. Large wetlands as well as lakes and ponds also maintain a higher level of groundwater in the surrounding area. People depend up on shallow private wells in region. 
WETLANDS DEGRADATION AND CONVERSION DUE TO URBANISATION IN MUMBAI METROPOLITAN REGION: ACUTE PROBLEMS WITH LONG TERM SOLUTIONS

Therefore the effects of wetlands on maintaining local groundwater levels can help ensure a constant supply. The flood water slows down in wetlands. It is allowing dirt and other sediments to settle out. Many pollutants in runoff from region, lawns and roadways like lead, pesticides and hydrocarbons, bind to sediments and the organic mucky soils of wetlands. Such process is called as de-nitrification. It is at work in wetland soils whereby bacteria break down nitrates. Nitrates enter water from many sources. It includes septic system, agricultural runoff. Fertilizer washed off lawns by rain. Nitrates can be toxic in excess amount. These substances from water only occur in wet soils that lack oxygen. Wetland plants also absorb and use nutrients and phosphorus helping to keep them out of rivers, lakes, water supplies. It was difficult to estimate the water supply through wetland because there is huge indirect and direct cost. But the wetland related water supply could have loss of Rs.39.42 crore during 1971-91. In 1991 2011, the loss due to destruction of wetland to water supply could be Rs. 985.50 crore. Few costs related to filtration cannot be estimated in region.

We have also estimated the loss of wetland and raw material availability in suburbs of region. This is mainly because mangroves provide honey, crustaceans, fish, fuel, alcohol, textile, paper products, sugar construction materials and fodder. It also provides research materials to the education and tourism department. The fertilizers, cooking gas and building materials are prepared from wetland resources. Wetlands impressive productivity is attributable for mud. Some scientists consider mud is not seawater. It is a grandmother of ecosystems. It is a combination of dirt, water resistant material. The wet land soil is generally replete with malodorous organic detritus. It is a major fish food. It is an ideal breeding ground for signal cell plants and animals in region. It is an important element at the base of the food chain. It yields fuel wood for cooking, thatch for roofing, fibers for textile and paper making. Wetland also provides timber for building. Wetland related medicines extracted from bark, leaves and fruits. They also provide tannins and dyes. It is used extensively in the treatment of leather. Such raw material extracted and collected at small quantity in region. We estimated that decline of wetland could have loss of Rs 39.42 crore to raw material during 1971-91 period. In 1991-2011, raw material could have cost of Rs. 985.50 crore in region. Most of the poor families in region regularly go to wetlands and bring fuel wood for cooking. They cut mangroves and other trees and depend on it as fuel wood. We have estimated that Rs.12.26 crore could have lost due to plants and trees used as fuel wood by people in region. In 1991-2011, such figure could be Rs. 306.60 crore. Above table shows that during 1971-91 large destruction of wetland took place in region. We have estimated that around Rs. 1979 crore total loss could have taken place during 1971-91 periods. The major loss is observed for recreation in region. During 1991-2011, the total loss due to wetland destruction could be Rs.49494 crore. The loss is more for recreation (Rs.10774.80 crore) and flood control (Rs.10161.60 crore). Flooding is annual phenomena in region. Many houses, agricultural land human lives lost in floods. Such high loss is 
Rode S.

WETLANDS DEGRADATION AND CONVERSION DUE TO URBANISATION IN MUMBAI METROPOLITAN REGION: ACUTE PROBLEMS WITH LONG TERM SOLUTIONS

observed due to wetland destruction in region. We have estimated the loss according to the suburb in region. We have made an attempt to measure the loss due to wetland destruction according to suburb. Table below provides the annual loss in various suburbs of Mumbai Metropolitan Region.

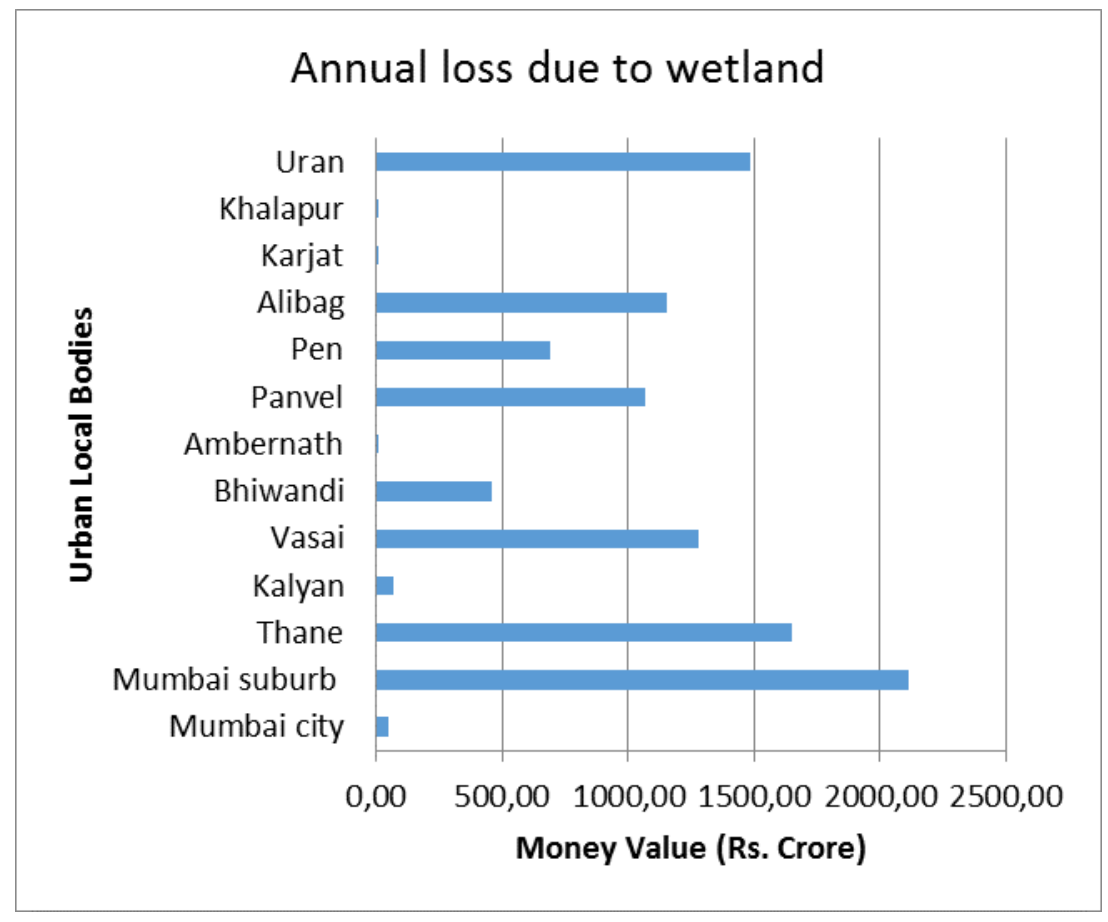

Figure 2 ANNUAL LOSSES DUE to WETLAND DESTRUCTION IN SUBURBS (RS. CRORE)

Source: calculated from data

Wetlands that contribute valuable ecosystem services to a notable number of people, the natural species habitat and tourism interests. Wetlands are epoch-making reproducing and nourishing zones for wildlife and give shelters and protection for sea creatures. As with any natural habitat, wetlands are important in supporting species diversity as well as providing the climate moderating element (Orimoloye I.R 2018). Above figure shows that the annual loss due to destruction of wetland in Uran could be more than Rs 1500 crore. In Alibag, the loss due to wetland destruction could be Rs. 1200 crore. In Panvel, wetland destruction loss could be more than Rs. 1100 crore. The loss due to wetland destruction in Vasai Virar could be more than Rs 1300 Crore. In Thane, wetland destruction cost could be more than Rs. 1600 crore. Such cost to region is much higher but efforts are not done to reduce this loss. In Mumbai suburb alone the wetland loss could be more than Rs. 2200 crore. If we measure the loss due to wetland loss as per different categories then we find the details in the following table. 
Rode S.

WETLANDS DEGRADATION AND CONVERSION DUE TO URBANISATION IN MUMBAI METROPOLITAN REGION:

ACUTE PROBLEMS WITH LONG TERM SOLUTIONS

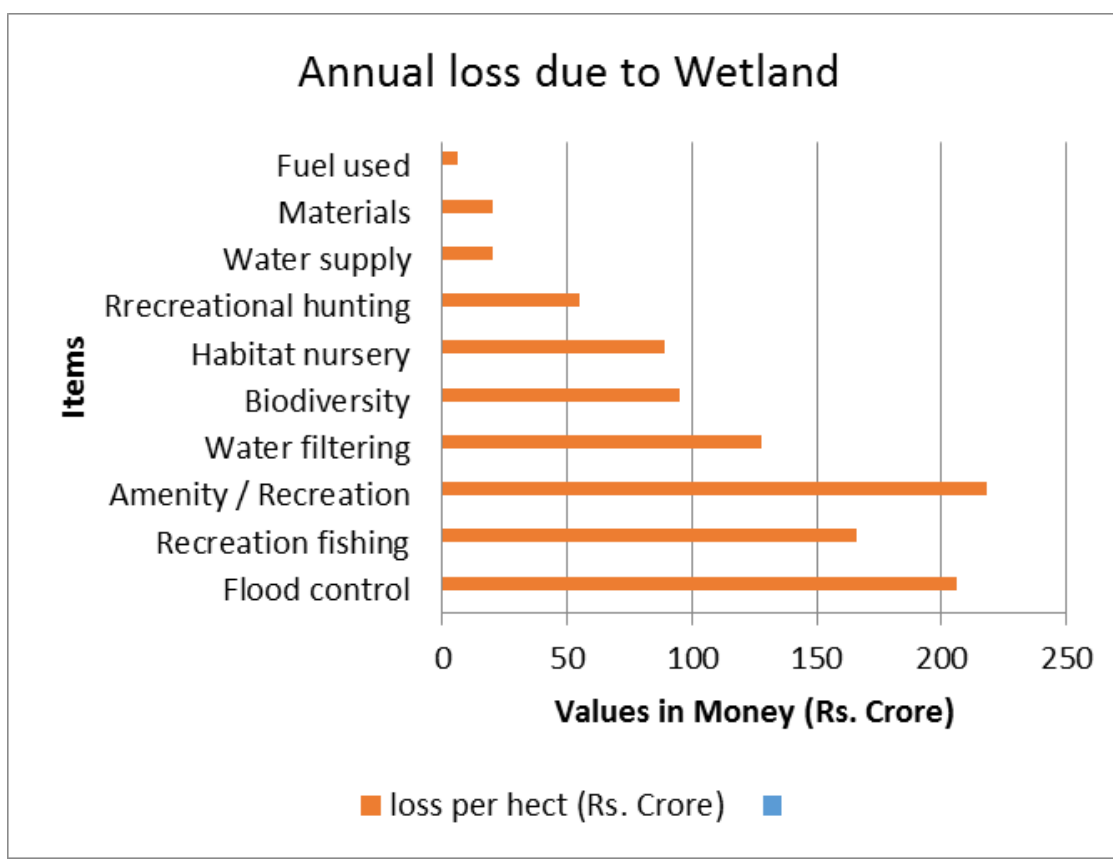

FIGURE 3 ANNUAL LOSS DUE TO WETLAND IN MMR (2016)

Source: calculated from data

Above figure shows that the recreation cost could be more than Rs 230 crore for region due to wetland loss. The flood control cost could be Rs 210 crore in region. The biodiversity loss could be close to Rs. 100 crore in region. Water supply is not affecting much because of wet land destruction in region. This is mainly because suburbs are not much depending on water supply from wet lands. The drinking water is brought from different dams to suburbs. But we have calculated that annual thousand crore loss could be taking place due to wetland destruction in region. State government needs to work on priority basis to protect wetland in region. Wetlands play a significant role in maintaining environmental stability. These have a complex of values like food storage, water quality maintenance, livelihood and support species diversity, etc. Wetlands inventory is the pre-requisite process for conservation and management practices (Ahmed R. et.al 2017). We tried to calculate the loss due to wetlands for region even though there are many limitations. Such calculations certainly give the insights for the policy implications.

\section{POLICY IMPLICATION AND CONCLUSIONS}

Wetlands provide vital habitats for a range of biota as well as ecosystem services for human communities. Wetland basins form on an array of landforms, with different water regimes, and their hydrology influences physical and chemical processes within the water column (Furlonge T. et.al 2015). Wetland ecosystems support food production, water supply, climate regulation, and culture. Wetlands 
Rode S.

WETLANDS DEGRADATION AND CONVERSION DUE TO URBANISATION IN MUMBAI METROPOLITAN REGION: ACUTE PROBLEMS WITH LONG TERM SOLUTIONS

have long supported a range of services including provision of water, control floods, fishing, dry season grazing areas, agriculture, and wildlife habitats (Ngowi N.J and Agnes Godfrey Mwakaje 2018). Wetland is essential for animals, birds and human being to live meaningful and dignified life. Wetland provide recreation, water, food, reduces flooding, maintain temperature. For birds and reptiles, it is a source of livelihood; many migrated birds find good climate and food near wetlands. Sustainable wetland helps to grow birds, animals and reptiles etc. In metropolitan region, urbanization is growing fast. Many people from rural and urban parts of state and other states are migrating in region. The growth of population is observed since many years in region. The population is demanding housing, sanitation, roads, recreation, markets, and educational facilities in region. Municipal corporations are working continuously to provide better infrastructural facilities to people. Every municipal corporation has unique land allocation and distribution. The land use pattern is earlier decided and such land use cannot be changed very easily. But population is increasing and new infrastructural projects are undertaken in few suburbs of region. The land is taken over from farmers. Government land is converted from forest to build up area. Farmers are selling and renting their agricultural land for different purposes. Cultivation of land is not possible due to industrial and housing projects. Educational achievements of people have increased in region. Therefore skills and employment opportunities are increasing. It has resulted in to high demand for housing and commercial units in region. Municipal Corporations are changing the land use from agricultural land to build up land. For industrial and government projects, the forest, wet land and land under water bodies is converted. There are different proportions of wet lands available in each municipal corporation and council in region. In Ulwe, the agriculture and forest land is converted for international airport, Oil and Natural Gas Corporation (ONGC), Jawaharlal Neharu Port Trust (JNPT) and Special Ecomic Zone (SEZ) projects. Forest and wetlands are converted to build up area. Many migrating birds are shifting to other locations due to destruction in wetland of region. The region is experiencing heavy loss due to destruction of wet lands and its services. Uran and Panvel have lost maximum hectares of wetland in region. The loss is estimated as Rs. 2500 crore per year. Therefore there is need of awareness about wetland in region. State government must protect and develop wetland in region. State government must pass the laws to protect wetlands in the region. Population in region required to know the area, uses of wetlands. The direct and indirect benefits are much higher of wetlands. The people in region are depending upon the wetlands for different services. Therefore an environmental education in schools and colleges could be useful to change behavioral pattern of people and protection of wetlands. The study focus on education and awareness curriculum for wetlands protection, community and non-formal education programs on wetlands (Ibrahima I. et.al 2012). 
Rode S.

WETLANDS DEGRADATION AND CONVERSION DUE TO URBANISATION IN MUMBAI METROPOLITAN REGION: ACUTE PROBLEMS WITH LONG TERM SOLUTIONS

The NGO's in region must create awareness related to wetland protection. There is need of commitment to protect the wetlands in region. State government and NGO's must prepare wetland data. They must prepare maps in details of wetlands in region. The NGO's, state government, village panchayats must count number of trees, birds, reptiles, types of fish, migratory birds near to wetlands. They must prepare the plan to protect wetlands and maintain it on sustainable basis. Those people are distracting the wetland, there is need to take strict action against them. Wetlands can be destroyed very easily and land can be converted for different purposes. Such movement is adversely affecting on the migratory birds, species, fishes and others. The livelihood of fisherman has already affected in suburbs. Ecosystem gets affected due to the destruction of mangroves and wetlands. In order to protect the wetlands and man grows; there is need of cooperation between various local bodies and state government. Most of the times, the state government protect wetland but district and regional bodies do not support its move related to wetlands. There are various NGO's in region which are focusing on the conservation of mangroves but their activities, efforts and suggestion are not appreciated by local and state government. Role of academic institutions and NGO's are important in protection of wetland in Mumbai Metropolitan Region. They are regularly raising the concern of wetlands in region through demonstration activities, articles in newspapers and television talk shows. A study suggested that people valued positive benefits of coastal wetland restoration, as it could improve the levels of mangrove area, water quality and biodiversity. The mangrove area is the most important attribute which need to be considered in the restoration strategy design, as it has the highest marginal willingness to pay value (Tan Y. et.al 2018). Every year, state government must conduct wetland survey along with the number of animals depending upon it. The NGO's must be provided financial assistance, technology and knowledge to protect the biodiversity in each suburb. Government must work with NGO's to execute the micro plan for wet land protection. It is the job of state government and Municipal Corporations and Councils to evaluate regular status of different wet lands in region. They must apply available worldwide best techniques and experts to develop wetlands in region. Wetlands grow and develop according to a myriad of highly variable inputs over time, including stochastic weather, random arrival events of species, competition, surface and groundwater interactions, and many others. The fluctuations and interactions of wetland ecosystems are more akin to human metabolism than they are to an automotive engine, with dynamic interacting components such as wetland soils, hydrologic regimes, riparian zones, and water chemistry that are linked to their surroundings (Clare S. et.al. 2011). Overall sustainable wetlands are important for humans, animals and species. Therefore their conservation and development is most urgent need in region. 
Rode S.

\section{NOTES:}

1. Data of landuse is provided by Mumbai Metropolitan Regional plan since 1971. The plan is given for twenty years. Therefore data is available for 1971,1991, 2011 and 2016.

2. The Mumbai Metropolitan Regional plan 2016 has given more categories of land use pattern in region the area of metropolitan region has increased over the period of time. The September 2016 draft of Mumbai Metropolitan Regional plan gives the land use for the future purposes that is 2016-2036. There are different categories of land in this report. Therefore such categories of land cannot be compared with the earlier categories of land use in region.

3. The land allocation pattern for different purposes has changed over the period of time by the Municipal Corporation and state government. Private and public land is used for different purposes.

4. All the wetlands are heterogeneous in terms of nature, size and shape . In order to study wetland and their status, we need to visit to each wetland and collect lot of data. Such time period was not available for this study. This study is purely based on secondary data and various reports.

5. Annual value of wetland function is derived from one hectare of wetland. The median weland values are given in the study of Schuyt Kirsten and Luke Brander (2004). We have used same median wetland economic values per hectare per year. The values are given in US Dollar. We have converted the values in Indian Rupees as $1 \$=$ Rs. 73 Rupees. The values are presented in the different tables. The climate regulation and potential values of tourism is not calculated in this study.

\section{ACKNOWLEDGEMENT:}

Author would like to thank to Dr. Indira Hirway, Director, Center for Development Alternatives, Ahmedabad for valuable inputs related to biodiversity in India. We conducted the study on coastal biodiversity and mangrove conservation in India.

\section{REFERENCES}

Ahmed, Raihan. Mehebub, Sahana., Haroon, Sajjad. (2017). 'Preparing turbidity and aquatic vegetation inventory for waterlogged wetlands in Lower Barpani sub-watersheds (Assam), India using geospatial technology' The Egyptian Journal of Remote Sensing and Space Sciences Vol.20(1):243-249. 
Baugha, James, W. La., Donald, O. Rosenberryb., David, M. Mushetc., Brian, P. Neffb., Richard, D. Nelsond, Ned, H. Euliss, Jr,. (2018). 'Long-term changes in pond permanence, size, and salinity in Prairie Pothole Region wetlands: The role of groundwater-pond Interaction' Journal of Hydrology: Regional Studies, Vol.17:1-23.

Berezowski, Tomasz., Martin, Wassen., Jan, Szatyłowicz., Jarosław, Chormanski., Ștefan, Ignar., Okke, Batelaan.,Tomasz, Okruszko. (2018). 'Wetlands in flux: looking for the drivers in a central European case' Wetlands Ecol Manage Vol. (26):849-863.

Biswasroy, M., Samala, N. R., Roy, P. K., Mazumdar, A. (2011).' Watershed management with special emphasis on fresh water wetland: A case study of a flood plain wetland in West Bengal, India' Global Nest Journal, Vol. 13(1):1-10.

Clare, Shari., Naomi, Krogman., Lee, Foote., Nathan, Lemphers. (2011). 'Where is the avoidance in the implementation of wetland law and policy?, Wetlands Ecol Manage (2011) 19:165-182.

Donaldson, Lynda., Anna, J. Woodheada., Robert, J. Wilsonb., llya, M. D. Maclean. (2016). 'Subsistence use of papyrus is compatible with wetland bird conservation' Biological Conservation Vol. 20:1:414-422.

Delaney, Jessica., Russell, J. Shiel., Andrew, W. Storey. (2016). 'Prioritising wetlands subject to secondary salinization for on-going management using aquatic invertebrate assemblages: a case study from the Wheatbelt Region of Western Australia' Wetlands Ecol Manage (2016) Vol.24:15-32.

Furlonge, Toni., Fiona, Dyera., Jenny, Davis. (2015). 'The influence of differing protected area status and environmental factors on the macro-invertebrate fauna of temperate austral wetlands Global Ecology and Conservation Vol.4:277-290.

Hudon, C., Jean, M., Létourneau, G. (2018). 'Temporal (1970-2016) changes in human pressures and wetland response in the St. Lawrence River (Québec, Canada)'Science of the Total Environment, Vol.643:1137-1151

Ibrahima, Irini., Noraini, Aminudinb. \& Michael, Andrew, Young., Suleiman, Abdullah, Ibn, Yahya. (2012). 'Education for Wetlands: Public Perception in Malaysia' Procedia - Social and Behavioral Sciences, Vol.42:159 - 165.

Josefin, Thorslunda., Jerker, Jarsjö, A., Fernando, Jaramilloa, B., James, W. Jawitzc., Stefano, Manzonia., Nandita, B. Basud., Sergey, R. Chalove., Matthew, J. Cohenf., Irena, F. Creedg., Romain, Goldenberga., Anna, Hylina., Zahra, Kalantaria., Antonis, D. Koussish., Steve, W. Lyona., Katerina, Mazih., Johanna, Mårdi., Klas, Perssona., Jan, Pietro'na., Carmen, Prietoa., Andrew, Quina., Kimberly, Van, Meterd., Georgia, Destounia, J. (2017). 'Wetlands as large-scale naturebased solutions: Status and challenges for research, engineering and management' Ecological Engineering Vol.108:489-497

Kolka, R. K., Murdiyarso, D. J., Kauffman, B., Birdsey, R. A. (2016). 'Tropical wetlands, climate, and land-use change: adaptation and mitigation opportunities' Wetlands Ecol Manage, Vol. 24:107-112

Norbert, John, Ngowi., Agnes, Godfrey, Mwakaje. (2018). 'Implementation effects of incentive policies on Tanzanian wetland ecosystems' Kasetsart Journal of Social Sciences Vol.30:1-8.

Orimoloye, Israel, R., Ahmed, M. Kalumba., Sonwabo, P. Mazinyo., Werner, Nel. (2018). 'Geospatial analysis of wetland dynamics: Wetland depletion and biodiversity conservation of Isimangaliso Wetland, South Africa' Journal of King Saud University - Science, Vol.30:1-7.

Phukan, Pratyashi. \& Ranjan, Saikia. (2014). 'Wetland Degradation and its Conservation: A case study of some selected wetlands of Golaghat district, Assam, India' Research Journal of Recent Sciences, Vol.3:446-454. 46 
Rode S.

Pedersen, Eja., Ștefan, E. B., Weisner, B., Maria, Johansson. (2019). 'Wetland areas' direct contributions to residents' well-being entitle them to high cultural ecosystem values' Science of the Total Environment, Vol. 646:1315-1326.

Ramachandra, T.V., Rajinikanth, R. \& Ranjini, V. G. (2005). 'Economic valuation of wetlands' Journal of Environment Biology,Vol. 26(2):439-447.

Rahman, Md. Mijanur., Yong, Jiang., Kenneth, Irvine. (2018). 'Assessing wetland services for improved development decision-making: a case study of mangroves in coastal Bangladesh' Wetlands Ecol Manage, Vol.26:563-580

Saaltinka, Rémon, Ștefan, M., Dekkera, C., Jasper, Griffioena., Martin, J. Wassen. (2018). 'Vegetation growth and sediment dynamics in a created freshwater wetland' Ecological Engineering, Vol. 111:11-21.

Schuyt, Kirsten. \& Luke, Brander. (2004). 'The Economic Values of the World's Wetlands' Prepared with support from the Swiss Agency for the Environment, Forests and Landscape (SAEFL), Gland/Amsterdam, January 2004.

Steven, D. \& Lowrance, Richard. (2011). 'Agricultural conservation practices and wetland ecosystem services in the wetland-rich Piedmont-Coastal Plain region' Ecological Applications, Vol. 21(3):3-17, Supplement, 2011.

Wang, Y., Yao, Y., Ju, M. (2008). 'Wise use of wetlands: current state of protection and utilization of Chinese wetlands and recommendations for improvement', Environ Manage., Vol. 41(6):793-808.

Woldemariam, Wondimu., Tariku, Mekonnen., Kerryn, Morrison., Abebayehu, Aticho. (2018). 'Assessment of wetland flora and avifauna species diversity in Kafa Zone, Southwestern Ethiopia' Journal of Asia-Pacific Biodiversity, Vol.30:1-9.

Woon-Kee, Paek. (2018). 'An avifaunal survey of middle Mongolian wetlands: Important Bird Areas and threatened species' Journal of Asia-Pacific Biodiversity, Vol.11:340-345.

Wondie, Ayalew. (2018). 'Ecological conditions and ecosystem services of wetlands in the Lake Tana Area, Ethiopia'Ecohydrology \& Hydrobiology, Vol. 18:231-244

Tan, Yonghua., Duian, Lv., Jie, Cheng., Degang, Wang., Wei, Mo., Yunyun, Xiang. (2018). 'Valuation of environmental improvements in coastal wetland restoration: A choice experiment approach Global Ecology and Conservation, Vol.15:1-8. 